\title{
Nietzsche en el anarquismo rioplantense (1890-1910) Consideraciones teóricas y metodológicas
}

\author{
Martin Cremonte* \\ Historicemos siempre! \\ Frederic Jameson
}

\section{Introducción}

No sería novedoso afirmar que la filosofía de Friedrich Nietzsche ha sido un campo de batalla.' El investigador Steven Aschheim, luego de un análisis detenido de la recepción en Alemania durante un siglo, observa que el nietzscheanismo significó una "proteica fascinación" y "contradictoria penetración" en la arena cultural y política. ${ }^{2}$ El nietzscheanismo, agrega Aschheim, se expresó como fenómeno policromático y plural. Por su parte, Alain Badiou nos ofrece una imagen inquietante del siglo XX. Según el pensador francés la época de Lenin, Hitler y Stalin fue "una llíada subjetiva" que se vivió "con un carácter heroico y épico" signada por Nietzsche. ${ }^{3}$ Un sutil estudioso como Carl Schorkse confiesa que la irrupción del niezscheanismo desbarata todas las categorías de la historia intelectual. ${ }^{4}$ Cualquier investigador que se interrogue por las consecuencias políticas de las ideas nietzscheanas vuelve a ser un Ulises en el ingrato pasaje entre la Escila de Georg

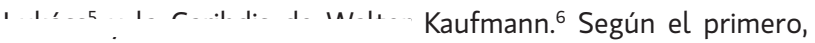

* UBA/UNSAM.

Este artículo no hubiera sido posible sin la valiosa colaboración de $\mathrm{Na}$ talia Bustelo, Matías Cottone, Daniel de Lucía y Lucas Domínguez Rubio.

2 Steven Aschheim, The Nietzsche Legacy en Germany 1890-1990, Berkeley, University of California Press, 1992, capítulo 1.

3 Alain Badiou [2005], El siglo, Buenos Aires, Manantial, 2008, p. 53.

4 "Con estas premisas conceptuales, mi curso de historia intelectual iba bastante bien...hasta Nietzsche. Allí surgían los problemas. En lo que parecía una fragmentación ubicua Nietzsche y los marxistas coincidían en denominarla 'decadencia', la alta cultura de Europa entraba en un remolino de innovación infinita...", Carl Schorske [1961], La Viena de fin de siglo, Buenos Aires, 2011, pp. 17 y ss.

5 Georg Lukács [1954], El asalto a la razón, México, FCE, 1959.

6 Walter Kaufmann, Nietzsche. Philosopher, Psychologist, Antichrist,
Nietzsche fue el ideólogo irracionalista del imperialismo y, luego, del fascismo. Según el segundo, el filósofo ha sido distorsionado por los nacionalsocialistas y su obra debe ser considerada pura de toda apropiación. Mientras tanto, el canto de sirena del gran estilo nietzscheano sigue perturbando al investigador actual.

Frente a este desafío y sin escapar a la disputa, nos parece interesante incursionar en las zonas aún no exploradas de la recepción nietzscheana. Si bien los estudios existentes han arrojado luz sobre el efecto múltiple de la filosofía del martillo en las áreas germano-hablantes y otras varias zonas culturales, es preciso destacar que la conjunción entre la filosofía nietzscheana y el nacionalsocialismo no fue un caso aislado.' Incluso antes del inicio de la primera guerra, en varias zonas del mundo surgió una "afinidad electiva" entre Nietzsche y las corrientes de extrema izquierda y de extrema derecha que conviene precisar. Podemos confiar en que el estudio de la recepción en nuestra provincia

Princeton, Princeton University Press, 1950. En realidad para Kaufmann el pensamiento nietzscheano era "apolítico" en el sentido de que su individualismo estaba más allá de los presupuestos político-sociales; ver Marina Cominos, "The Question of Nietzsche's Anti-Politics and Human Transfiguration", en Herman W. Siemens y Vasti Roodt (eds.), Nietzsche, Power and Politics Rethinking Nietzsche's Legacy for Political Thought, Berlin-New York, Walter de Gruyter, 2008, p. 88.

7 Frank Krummel, Nietzsche und der deutsche Geist, 2 vols., Berlín/Nueva York, Walter de Gruyter, 1974/1983; Bruno Hillebrandt, Nietzsche und die deutsche Literatur, 2 vols., Múnich, Dtv, 1978; Hinton Thomas, Nietzsche in German Politics and Society 190-1910, Manchester, Manchester University Press, 1983; y Steven Aschheim, op. cit.. Para nuestra área latinoamericana la recepción francesa fue determinante: Gèneviève Bianquis, Nietzsche en France, Paris, Alcan, 1929; Jacques Le Rider, Nietzsche en France. De la fin du XIX siécle au temps présent, Paris, Presses Universitaires de France, 1999 y José Sazbón, Nietzsche en Francia, Bernal, Universidad Nacional de Quilmes, 2009. Para la bibliografía en otras partes del mundo ver Steven Aschheim, op. cit., p. 1. 
latinoamericana puede completar el cuadro de las concreciones políticas del nietzscheanismo.

Hasta el momento, no contamos con un relevamiento amplio de fuentes para poder analizar el impacto de los conceptos nietzscheanos en el Río de la Plata durante la crisis de la república oligárquica hasta la emergencia y derrumbe de la república democrática. ${ }^{8}$ Desde la historia intelectual aún está pendiente una reflexión sobre el lugar de Nietzsche y el nietzscheanismo. Para atenuar esta postergación, a continuación nos proponemos dos objetivos: a) identificar la corriente anarconietzscheana para el estudio de la Nietzsche-Rezeption en nuestra región y b) reconstruir el efecto político del nietzscheanismo en el seno de la hegemonía positivista.

Podríamos afirmar que las historias de recepción de ideas representan un subgénero de la historia intelectual cada vez más frecuentado en nuestro país. ${ }^{9}$ Sin embargo, los estudios sobre la difusión temprana (1890-1930) de las ideas nietzscheanas en las distintas zonas de Latinoamérica no son abundantes ni satisfactorios. El único texto integral dedicado a la recepción de Nietzsche en Iberoamérica, Nietzsche in der Hispania (1962) de Udo Rukser, ${ }^{10}$ nos ofrece un panorama fragmentario, poco sistemático y sin recursos hermenéuticos para plantear problemas." En cuanto a los artículos posteriores relativos a la recepción en la Argentina con cierto alcance panorámico, podemos destacar sendos trabajos de Lucía Piossek Prebisch y de Mónica Cragnolini. ${ }^{12}$ El problema de estos aportes es que tampoco utilizan cate-

8 Como criterio general consideramos a Buenos Aires y Montevideo dentro de un mismo contexto "rioplatense".

9 Sólo para destacar algunos ejemplos importantes: José Aricó, La cola del diablo. Itinerario de Gramsci en América Latina, Buenos Aires, Punto Sur, 1988; Hugo Vezzetti, Freud en Buenos Aires 1910-39, Buenos Aires, Punto Sur, 1989; Jorge Dotti, La letra gótica. La recepción de Kant en la Argentina desde el romanticismo hasta el treinta, Buenos Aires, Facultad de Filosofía y Letras, 1992; Jorge Dotti, Carl Schmitt en Argentina, Buenos Aires, Homo Sapiens, 2000; Mariano Plotkin, Freud en las pampas, Buenos Aires, Sudamericana, 2003; Horacio Tarcus, Marx en la Argentina: sus primeros lectores obreros, intelectuales y científicos Buenos Aires, Siglo XXI, 2013; y Mariana Canavese, Los usos de Foucault en la Argentina. Recepción y circulación dese los años cincuenta hasta nuestros días, Buenos Aires, Siglo XXI, 2015.

10 Udo Rukser, Nietzsche in der Hispanian, Bërn/ München, Francke Verlag, 1962. Respecto al área española, cabe destacar la vasta obra de Gonzalo Sobejano, Nietzsche en España, Madrid, Gredos, 1967. Esta investigación aporta una apreciable cantidad de fuentes que abarcan y desbordan el contexto del período temprano. Desde el punto de vista heurístico, el logro de Sobejano es destacable pero su empirismo ingenuo, poco atento a la mediación hermenéutica, resta valor a este gran emprendimiento.

11 Por ejemplo, la figura estratégica de Almafuerte no es siquiera mencionada por Rukser. Tampoco son mencionados Julio Molina y Vedia ni Carlos Octavio Bunge. Acaso la fuente más importante del período temprano, los escritos de Manuel Gálvez, no fueron consultados por el investigador alemán. En cambio, sí son tratados Mariano Antonio Barrenechea, Leopoldo Lugones y José Ingenieros. Al uruguayo Carlos Reyles se le dedica una página. Pero quizá el punto más débil de Nietzsche in der Hispanian se encuentra en la escasa atención que merece la reconstrucción del período temprano como sistema autónomo de lectura.

12 Lucía Piossek Prebisch, "Para una historia de las ideas. La recepción de Nietzsche", en Cuadernos de Filosofía, n²1, Buenos Aires, 1995, pp. 119-132 y Mónica Cragnolini, "Nietzsche en la Argentina entre 1880 y gorías semióticas de análisis ni reconstruyen el microsistema de La recepción temprana; a lo anterior hay que agregar que la valoración filosófica sin "hermenéutica de la sospecha" predomina por sobre el trabajo de historización. A contrapelo de esta tendencia, nuestra tesis de licenciatura de 2005 intentó ampliar la base heurística de análisis y plantear otras posibilidades interpretativas a las posturas mencionadas. ${ }^{13}$ El objetivo más importante fue explicitar los presupuestos ideológicos para ofrecer algunas objeciones a cierto sentido común posmoderno y a la "filosofía de la diferencia".14 Por su parte, María Pía López ha escrito un gran ensayo dedicado al vitalismo argentino en los años veinte que va en dirección opuesta a nuestra perspectiva. Según la investigadora, su texto nace como producto de una "incomodidad", a saber: la relación entre vitalismo y fascismo. Oponiéndose a la línea historiográfica que comienza en Georg Lukács y culmina con Zeev Sternhell, ${ }^{15}$ María Pía López sostiene que no se puede determinar una relación "causal" y "lineal" entre el movimiento vitalista y el fascismo. Por cierto, este aporte significa un mayor esfuerzo de historización que los trabajos anteriores. ${ }^{16}$

Más allá de que existe una variedad de opciones teóricas para reconstruir la producción, circulación y recepción de los conceptos, resulta relevante ejercitar la potencialidad de un modelo pragmático. Si no nos equivocamos en la generalización, en nuestro medio predomina la tendencia a concebir todo proceso de recepción como "uso" y "apropiación". Esto es, los sujetos de recepción predominan por sobre los textos y conceptos operantes. Nos interesa objetar este modelo instrumental en favor de una pragmática interactiva y dialéctica. ${ }^{17} \mathrm{Y}$ este camino comienza por un recaudo contextualista básico: reconstruir la "intención del texto", lo cual supone defender una mínima distinción en-

1945: alusiones y citaciones en los márgenes", en Instantes y Azares, ${ }^{\circ}$ 1, 2001, pp. 107-123.

13 Martín Cremonte, La recepción temprana de Nietzsche en el Río de la Plata (1890-1920), Tesis de Licenciatura, Universidad de Buenos Aires, Facultad de Filosofía y Letras, 2005

14 Para este concepto, ver Gianni Vattimo [1980], Las aventuras de la diferencia, Barcelona, Península 1986. Nuestra posición se inspira en la primera crítica sistemática, por parte de Jürgen Habermas, a las distintas formas de antimodernismo, especialmente, a la filosofía de la diferencia, desde Friedrich Nietzsche, Martin Heidegger hasta Michel Foucault, cfr. Jürgen Habermas [1985], El discurso filosófico de la modernidad, Buenos Aires, Katz, 2008

15 George Lukács [1954], El asalto a la razón, México, FCE, 1959 y Zeev Sternhell et ali. [1989], El nacimiento de la ideología fascista, Madrid, Siglo XXI, 1994

16 María Pía López, Hacia la vida intensa. Una historia de la sensibilidad vitalista, Buenos Aires, Eudeba, 2010. Otro aporte de esta investigadora a los estudios nietzscheanos locales es la introducción a Julio Molina y Vedia [1904], Hacia la vida intensa, Buenos Aires, Colihue, 2006.

17 Nuestra aproximación a la pragmática tiene en cuenta los desarrollos de Ludwig Wittgenstein [1953], Investigaciones filosóficas, Barcelona, Crítica, 2004; John Austin [1962], Cómo hacer cosas con palabras, Buenos Aires, Paidós, 1982; John Searle [1969], Actos de habla. Ensayo de filosofía del lenguaje, Buenos Aires, Planeta-Agostini, 1994; y Quentin Skinner, Lenguaje, política e historia, Bernal, Universidad Nacional de Quilmes, 2007 
tre el uso y la interpretación de los enunciados. ${ }^{18}$ En el modelo unilateral de los "usos", se pierde de vista el efecto mismo de la intencionalidad de los textos. En otras palabras, al privilegiar la dimensión perlocutiva de los enunciados se deja de lado su fuerza ilocutiva. Pero acaso la omisión más objetable de tal perspectiva se refiere a que no atiende la dialéctica entre el texto y el receptor en contexto, es decir, que no se pone en marcha una concepción pragmática integral.

Por nuestra parte, optamos por la historia conceptual articulada con una concepción pragmática de la investigación histórica. Esto significa considerar, en principio, una dinámica más compleja que la mera relación lector-obra: las condiciones de producción y recepción del sentido deben considerarse "en un funcionamiento circular que incluye la conjunción entre el decir y el hacer."19 Este último objetivo invita a entrar de lleno en la ardua polémica sobre las implicancias prácticas del pensamiento nietzscheano. Tal como proponemos reconstruir, la actualidad de este intenso debate se puede apreciar en la tensión entre la perspectiva historicista-crítica de Domenico Losurdo en su Nietzsche: Il ribelle aristocratico, ${ }^{20}$ por un lado, y la posición filológica de Kilian Lavernia Biescas, por otro, en uno de los últimos y más importantes trabajos sobre la Nietzsche-Rezeption producidos en el área de lengua española. ${ }^{21} \mathrm{El}$ investigador italiano reconstruye la historicidad del pensamiento nietzscheano (el texto en su contexto, digamos) y arremete contra la "hermenéutica de la inocencia" que niega las implicancias políticas de aquél. ${ }^{22}$ Por su parte, Kilian Biescas confía en que la responsabilidad hermenéutica y la probidad filológica conducen tanto a afirmar la profundidad y la productividad del pensar nietzscheano como a sostener su autonomía con respecto a ciertas versiones políticas. Digamos que la primera cuestión está fuera de discusión pero, en cambio, la segunda merece una nueva consideración que permita ensayar algunas hipótesis alternativas a la "hermenéutica de la inocencia", o bien a la tesis de la responsabilidad filológica de Kilian Biescas. En nuestro caso, fieles al imperativo de historizar "avant tout les choses", nos proponemos abordar la recepción temprana de la filosofía nietzscheana en el Río de la Plata mediante la siguiente estrategia: en primer lugar, reconstruimos una red de conceptos que exceden a un corpus escrito definido y que, además, tienen una fuerza ilocucionaria específica; en segundo lugar,

18 Para esta distinción que nos parece fundamental para el subgénero de la historia de la recepción, ver Umberto Eco [1990], Los límites de la interpretación, Barcelona, Lumen, 2000 y también [1992], Interpretación y sobreinterpretación, Madrid, Cambridge University Press, 1997.

19 Eliseo Verón, La semiosis social. Fragmentos de una teoría de la discursividad, Barcelona, Gedisa, 1993, p. 124

20 Domenico Losurdo, Nietzsche, Il ribelle aristocratico, Torino, Bollati Boringhieri, 2002.

21 Kilian Lavernia Biescas, La recepción del pensamiento Nietzsche en la historia de sus ediciones, Tesis Doctoral, Madrid, UNED, 2017. Conviene aclarar, como su título lo dice, que se trata de una historia de la recepción a través "de sus ediciones".

22 Para este concepto ver el apéndice de Domenico Losurdo, op. cit., pp. 1077 y ss. establecemos que la textualidad escrita representó un factor secundario respecto a la recepción oral, indirecta, fragmentaria e intertextual. En cuanto a la trama política del período, en las conclusiones destacaremos el rol hegemónico de los "reformistas liberales" y su interacción específica con el nietzscheanismo. ${ }^{23}$ Mientras que las huelgas obreras aumentaban en cantidad e intensidad y la fracción roquista perdía el poder, los gobernantes reformistas alternaron los mecanismos represivos como las soluciones legislativas. ${ }^{24} \mathrm{Al}$ final interpretaremos la fuerza ilocucionaria de los conceptos nietzscheanos como cierto efecto político en el seno de la hegemonía positivista, con especial referencia a la eugenesia.

\section{Reconstrucción semántica}

Para el historiador conceptual la semántica de los textos de un filósofo (su "pensamiento") se puede reconstruir por medio de un conjunto limitado de conceptos fundamentales. Cada uno de estos conceptos fundamentales debería tener, como primera condición, la peculiaridad de condensar la intersección de varios otros conceptos. De manera que el "pensamiento" del filósofo en cuestión puede resumirse en una red de significaciones conceptuales en las que las distintas "isotopías" 25 se van confirmando en un conjunto coherente. En nuestro caso, comenzamos por retomar la reconstrucción de cinco conceptos clave realizada por Martín Heidegger respecto al último período de la filosofía nietzscheana, a saber: el nihilismo (Nihilismus), la transvaloración de todos los valores (Umwertung aller Werthe), la voluntad de poder (Wille zur Mach), el eterno retorno (Die ewige Widerkehr) y el superhombre (Übermensch). ${ }^{26}$ Dado que el pensar ontológico de Heidegger omite algunos otros sentidos fundamentales, es necesario reponer también la dimensión materialista-instintivista de la antropología nietzscheana así como su dimensión vitalista. En otras palabras, agregamos el "hilo conductor del cuerpo", esto es, la serie de significaciones que se articulan en torno al concepto de cuerpo (Körper; Leib), al de instinto (Instinkt) y al de vida (Leben). Ellos convergen y explican la Wille zur Mach. ${ }^{27}$ También

23 Cfr. Eduardo Zimmermann, Los liberales reformistas, Buenos Aires, Sudamericana, 1995 y Natalio Botana [1977], El orden conservador, Buenos Aires, Hyspamérica, 1986.

24 Julio Godio, Historia del movimiento obrero. Inmigrantes asalariados y lucha de clases 1880-1910, Buenos Aires, Tiempo contemporáneo, 1973.

25 Para la categoría de "isotopía", ver Algirdas Greimas [1966], Semántica estructural, Madrid, Gredos, 1971 y [1976] La semiótica del texto: ejercicios prácticos, Buenos Aires, Paidós, 1983

26 Cfr. Martín Heidegger [1961], Nietzsche, vol.2, Barcelona, Destino, 2000, p. 40 y ss. También cfr. Michael Haar [1974], "Friedrich Niezsche", en Historia de la filosofía, vol.8, La filosofía en el siglo XIX, México, México, Siglo XXI, 1983, pp. 398-450.

27 Para los conceptos principales de la filosofía de Nietzsche, ver Christian Niemeyer (ed.), Diccionario Nietzsche. Conceptos, obras, influencias y lenguajes, Madrid, Biblioteca Nueva, 2012. Desde luego, la elaboración de un lexicón requiere una reconstrucción semántica previa. Por tanto, 
es preciso reponer otra constelación de conceptos fundamentales tales como perspectivismo (Perspecktivismus), genealogía (Genealogie) y experimentación (Versuchung). Esta ampliación tiene por objeto incorporar tanto la epistemología del filósofo como su específica evaluación de la multiplicidad de fuerzas que chocan en el cuerpo y en el seno de una cultura. ${ }^{28}$ Por otra parte, el carácter abierto y provisorio de la experimentación también es un factor cohesivo a tener en cuenta en la reconstrucción.

Pero aún nos falta identificar aquellos conceptos prácticos que tienen una relación más inmediata con la acción. En este sentido, podemos derivar de la anterior constelación otra red de conceptos políticos, a saber: gran política (grosse Politik), moral aristocrática (vornehmen Moral), pathos de la distancia (Pathos der Distanz), crianza (Züchtung) y jerarquía (Rangordnung). La calificación de "aristocrático radical" por parte de Georges Brandes, retomada por Losurdo, resume bien la singular ubicación ideológica del filósofo. ${ }^{29}$ Toda la red de conceptos converge en posiciones políticas (aunque se presente como una "antipolítica", tenemos el derecho o, más bien, la obligación, de descartar un ideario neutral ${ }^{30}$ ) en contra de la revolución francesa. Es decir, en contra del proyecto emancipatorio basado en la igualdad. Cristianismo, modernidad, plebeyismo, socialismo y anarquismo son figuras de la decadencia intercambiables para el filósofo. El proyecto nietzscheano para el futuro se basa en una recuperación de la política de los antiguos. O mejor aún: de las elites guerreras indoeuropeas ("arias"). Cuando el filósofo bosqueja su plan de transformación radical propone la figura del legislador Manu. La crianza debe asegurar el predominio aristocrático por sobre todo el intento de rebelión de los "decadentes". Por tanto, resulta fundamental tener en cuenta los pares opuestos tales como noble/ vulgar, sano/enfermo y fuertes/débiles.

Una segunda consideración a propósito de la fuerza ilocutiva de los conceptos políticos. Conviene interpretar esta dimensión como la inserción de los conceptos biológicos del nietzscheanismo, por ejemplo, en las prácticas eugenésicas. ${ }^{31}$ De manera que cuando nos referimos a conceptos operantes estamos indicando

la elección de los términos, tópicos y otros nudos semánticos pueden ser más o menos afortunadas. La empresa colectiva del Nietzsche-Lexikon, dirigida por Christian Niemeyer, consta de 421, escritas por 142 especialistas de distintos países y con un respaldo bibliográfico digno de destacarse.

28 Gilles Deleuze [1967], Nietzsche y la filosofía, Barcelona, Anagrama, 1994, pp. 80 y ss.

29 George Brandes, "Aristokratischer Radikalismus. Eine Abhandlung über Friedrich Nietzsche", en Deutsche Rundschau, 63, 1890, pp. 52-89. La edición que circulaba en el Río de la Plata en el período temprano fue Jorge Brandes, Nietzsche, Buenos Aires, Tor, 1927.

30 Basta mencionar el caso más paradigmático, Thomas Mann [1918], Consideraciones de un apolítico, Barcelona, Grijalbo, 1978. Este famoso documento generacional muestra que entonces la posición "apolítica" en defensa de la cultura (Bildung) significó adhesión al nacionalismo germano y fascinación por Nietzsche.

31 Para la relación entre la eugenesia y la filosofía nietzscheana, ver Domenico Losurdo, op. cit., pp. 626 y ss. una muy concreta implicación de éstos en las prácticas sociales. En otras palabras, el historiador conceptual debe reconstruir las condiciones de producción y recepción bajo la figura de un círculo de interacción y cooperación pragmática. No importa solamente la significación "intencional" del enunciador o el contexto de recepción sino la interacción dentro de un círculo hermenéutico-pragmático. No basta con las condiciones de lectura sino que es preciso entender los conceptos como factores y efectos de las prácticas sociales. ${ }^{32}$ Así es que, cuando un autor local utiliza el concepto nietzscheano de "crianza", decimos que éste es un "concepto operante" porque i) se vincula efectivamente con una sentido esctructurante una isotopía de la textualidad nietzscheana, ii) remite a la red de otros conceptos del filósofo, iii) a otras conexiones intertextuales (Malthus, Darwin, Galton, Renan, etc.), y iv) tiene una fuerza ilocucionaria de propuesta de acción, como, por ejemplo, las prácticas eugenésicas.

Por último, nuestro principio ordenador consiste en el supuesto último de que la política nietzscheana se condensa en la tesis de la desigualdad (Ungleichheit) humana. A partir de este punto podemos corroborar que la red de sentidos del pensamiento del filósofo se reconstruye en toda su riqueza e intencionalidad ideológica. Esto quiere decir que el concepto de "jerarquía" o "gran política" cobra sentido cuando lo vinculamos al principio de la desigualdad humana. Precisamente, la impugnación de Nietzsche a la modernidad política, esto es, al acontecimiento de la revolución francesa, adquiere sentido según la tesis de la desigualdad humana. Ahora bien, el estatuto de este último supuesto es, ni más ni menos, que el de un principio heurístico. Su utilidad reside en la posibilidad de construir una interpretación más rica. Frente a aquellas interpretaciones que postulan el carácter asistemático y fragmentario del pensar nietzscheano, proponemos la hipótesis de una coherencia unificadora, más allá de la racionalidad clásica, digamos. El concepto fundamental que consideramos centro del proyecto nietzscheano es el de vida (Leben). ${ }^{33}$ La red de otras significaciones fundamentales que hemos explicitado remite a este núcleo intencional. De manera que concebimos la constelación

32 En palabras de Reinhart Koselleck, los conceptos "son los materiales de un campo de investigación que considera el lenguaje político y social, en especial su terminología, simultáneamente como factores e indicadores del movimiento histórico", en "Introducción al Diccionario de conceptos políticos sociales básicos en lengua alemana", en Revista Ánthropos, $n^{\circ} 223,2009$, pp. 93-94. O bien: “... la historia conceptual no tiene su fin en sí misma, incluso aunque siga su propio método. Al proporcionar indicadores y factores a la historia social, la historia conceptual puede definirse como una parte metódicamente autónoma de la investigación en historia social", Reinhart Koselleck, Futuro pasado, Barcelona, Paidós, 1993, pp. 121-122. Ver también la capacidad poiética y organizativa de los conceptos, en António M. Hespanha, "Categorías. Una reflexao sobre a prática de clasificar", en Análise Social, vol XXXVIII, 2003, pp. 823-840.

33 "Es este concepto de vida, este concepto, el más alemán, el más goetheano, y conservador en el sentido supremo, religioso, es en el que Nietzsche con un nuevo sentimiento, el que revistió con una nueva beLleza, fuerza y sacrosanta inocencia, el que elevó al rango supremo, el que condujo a la supremacía espiritual", Thomas Mann, op. cit., p. 103. Para el concepto de vida en nuestro filósofo, ver George Simmel [1907], Schopenhauer y Nietzsche, Buenos Aires, Kier, 1944. 
de sentidos utilizando la guía tanto del concepto de desigualdad como del de vida.

\section{Textos, contextos y conceptos}

Decíamos que el trabajo de interpretación debe comenzar por el reconocimiento de configuraciones mínimas de sentido que operan antes de la lectura. Las distintas formas de actualización de las ideas nietzscheanas fueron "versiones" o formas básicas de interpretación a las que denominaremos "operadores discursivos". De manera que la primera pauta interpretativa importante consiste en señalar que no existió una única versión del nietzscheanismo sino que encontramos una pluralidad de apropiaciones. Ocho operadores discursivos, eventualmente, fueron determinantes en la recepción temprana de Nietzsche en el Río de la Plata: el anarquismo, ${ }^{34}$ el idealismo arielista, el dandismo esteticista, el materialismo, la psicopatología, el anticlericalismo y el nacionalismo. Estos operadores se combinaron y rechazaron siguiendo una dinámica propia. Tal fue el microsistema temprano que se extendió hasta 1930 y puede dividirse en dos subperíodos, tomando como eje el período de la primera guerra: desde 1890 a 1913 y desde 1914 a 1930.

Como lo señalamos antes, para nuestra perspectiva los operadores discursivos tienen prioridad expositiva por sobre los textos y las prácticas de lectura. Cuando una investigadora como Lavernia Biescas, en nuestro marco actual, se pregunta por la fidelidad filológica que se requiere para interpretar con "responsabilidad hermenéutica" la filosofía nietzscheana, instituye un marco intelectual totalmente ajeno a los parámetros y dinámica del período temprano. Ocurre que el texto nietzcheano del período temprano difiere considerablemente de nuestro texto actual.

Para restituir la estructura compleja de lo que podemos considerar el "texto nietzscheano amplio de la recepción temprana" debemos tener en cuenta los siguientes componentes: i. la textualidad oral de i.a) las citas (en general aforismos) que se transmitían, y i.b) los tópicos (la muerte de Dios, el superhombre, etc.); ii. la vulgata propiamente dicha (el estereotipo del superhombre de masas); iii. los operadores discursivos que ya suponen una reconfiguración de los conceptos nietzscheanos y por último, iv: el corpus de escritos que en el período temprano se conformó como obras estables en la edición francesa de Mercure a cargo de Henri Albert. ${ }^{35}$ Nótese que este último componente fue

34 Debemos recordar la doble faz del anarquismo: los individualistas son nietzscheanos mientras que los pro-organizadores son acérrimos antinietzscheanos.

35 Cfr. Jacques Le Rider, op. cit., p. 62. La edición francesa de Henri Albert tenía como referencia la tercera edición de las obras completas del Nietzsche-Archiv, la llamada Grossktavausgabe. Iniciada en 1899, este emprendimiento fue el canon textual durante casi sesenta años en Alemania y fuera de Alemania. Ver también Kilian Lavernia Biescas, op. cit., p. 103. subsidiario en el período temprano porque los otros tres determinaron la organización misma del texto ampliado.

Es preciso subrayar que el carácter predominantemente oral del texto amplio de la recepción incluía también una zona de rumores. La obra testimonial de Manuel Gálvez ofrece un extenso anecdotario, lo suficientemente vasto como para ilustrar las vicisitudes chismográficas que componían este circuito de oralidad. Por otro lado, el surgimiento y consolidación de un sistema de conferencias, configuró una peculiar forma de comunicación. ${ }^{36}$ Como bien observa Suriano, los anarquistas fueron los pioneros en la creación de una amplia red de conferencias como herramienta de propaganda y difusión. ${ }^{37}$

Mención aparte merecen los tópicos, las citas aisladas y los libros mediadores. A partir de nuestro rastreo biblio-hemerográfico podemos precisar que los tópicos más comunes fueron el "superhombre" y la "voluntad de potencia", los cuales por sí solos identificaban la filosofía nietzscheana. Por ejemplo, la "voluntad de potencia" en clave darwinista aludía a la lucha por la supervivencia del más apto; en clave aristocrática fue la "ideología de la fuerza" de Carlos Reyles y en clave anarquista se convirtió en "expansión individual". El tópico del "nihilismo" fue ubicuo y siempre en relación con el "amoralismo". El concepto de "decadencia" fue otro lugar retórico. La "transvaloración de todos los valores" aparece también como un núcleo identificable. Por ejemplo, Carlos O. Bunge, desde la disidencia, demostró ser un lector capaz de advertir la importancia de la "trasmutación". ${ }^{88}$ En cambio, la figura del "eterno retorno" fue sub-interpretada. Las referencias a este concepto-límite fueron muy escasas; el pensador uruguayo Carlos Vaz Ferreira fue uno de los pocos en realizar algún comentario al respecto. ${ }^{39}$ En general, las alusiones siempre se agotaban en la comparación con la "teoría de los ciclos" de los estoicos.

En cuanto a la función de las citas como formas de comunicación intelectual, podemos tomar el ejemplo de una de las consignas más repetidas: "Nada es verdadero, todo está permitido..." de la Genealogía de la moral (III). Esta cita concentraba el núcleo "amoralista" de la interpretatio temprana de la filosofía nietzscheana, y lo primero que hay que decir es que el filósofo, en rigor, se había apropiado de un tópico folletinesco: el lema perteneciente a la supuesta "Orden de los asesinos". Por último, entre los libros mediadores, destaquemos los casos más importantes de la recepción temprana: Dégénérescence (1892) de Max Nor-

36 Para la importancia de las conferencias como modos de comunicación cultural, cfr. Beatriz Sarlo y Carlos Altamirano [1983], "La Argentina del Centenario: campo intelectual, vida literaria y temas ideológicos", en Ensayos argentinos, Buenos Aires, Ariel, 1997, p. 175

37 Ver Juan Suriano, Anarquistas. Cultura y política libertaria en Buenos Aires, Manantial, 2001, cap. 6.

38 Carlos Octavio Bunge, Estudios filosóficos, Buenos Aires, Vaccaro, 1919, p. 243.

39 Carlos Vaz Ferreira [1904], "Nietzsche", en Tres filósofos de la vida. Nietzsche, James, Unamuno, Buenos Aires, Losada, 1965. 
dau, la obra de Gabriel D' Annunzio para el campo literario y los ensayos filosóficos de Alfred Fouillée para la recepción académica.

Sería difícil exagerar la importancia de la vulgata nietzscheana encarnada en el estereotipo de los superhombres de masas en la cultura popular rioplatense. ${ }^{40}$ Fue Antonio Gramsci quien propuso una hipótesis genial para los estudios literarios y para la historia de la cultura popular: "Me parece que se puede afirmar que una gran parte de la autodenominada 'superhumanidad' nietzscheana tiene como único origen y modelo doctrinal no a Zaratustra sino a El conde de Montecristo de A. Dumas", "de ahí el éxito de algunos eslogans como: 'es mejor vivir un día como un león que cien años como oveja', ${ }^{41}$ éxito particularmente grande en quien es, propia e irremediablemente, una oveja. Cuántas de estas ovejas dicen: oh, si yo tuviese también el poder por un día solo, etc.; ser 'justicieros' implacables es la aspiración de quienes sienten la influencia de Montecristo". Lo cierto es que el estereotipo del superhombre aparece profusamente tanto en la publicidad 42 como en la literatura local. En la vasta producción de folletines criollos de 1880 a 1900, por ejemplo, la figura de gaucho malo, como Moreira u Homiga Negra, constituyen variantes locales del estereotipo. ${ }^{43}$ También Beatriz Sarlo ha señalado la continuación del superhombre decadentista dannunziano en el ciclo de ficciones populares de La novela semanal (1913-1927).44

En cuanto al corpus de escritos disponibles en el período temprano, en el Río de la Plata los textos de Nietzsche llegaron, casi exclusivamente, por las traducciones francesas. Este fue el orden cronológico de dichas versiones: Ansi parlait Zarathoustra (1898), Par-delà le bien et le mal (1898), Humain, trop humain (1899), Pages choisis (1899), La généalogie de la morale (1900), L'origine de la tragédie (1901), Aurore (1901), Le gai savoir (1901), Le voyageur et son ombre (1902), La volonté de puissance (1903), Crépuscule des idoles (1906), Le cas Wagner

40 Cfr. Antonio Gramsci, Literatura y vida nacional, México, Juan Pablos Editor, 1986, pp.142-153. Por otra parte, Gramsci observa que la ideología del superhombre de masas responde a los ideales justicieros de la pequeña burguesía. Agrega que existe la posibilidad de que el mismo Nietzsche se inspirara en este estereotipo de superhombre de los folletines. Umberto Eco ha resumido y ampliado la hipótesis gramsciana, cfr. Um berto Eco [1978], El superhombre de masas, Barcelona, Lumen, 1998.

41 Máxima que utilizaba Mussolini quien además, como se sabe, fue admirador de Nietzsche.

42 Ana Asprea, "La presencia de Nietzsche en Caras y Caretas. El superhombre del tónico Sargol", en Instantes y Azares, $n^{\circ} 1$, Buenos Aires, Eudeba, 2001, pp. 217-229.

43 Según Adolfo Prieto, los gauchos malos son, en realidad, "superhombres inventados para cubrir las fantasías del lector urbano. Pero superhom bres que necesitaban presentarse en el ropaje de gauchos", cfr. Adolfo Prieto, El discurso criollista en la formación de la Argentina moderna, Buenos Aires, Sudamericana, 2006, p. 97. El investigador remite a Gramsci y Eco.

44 "La chica del cine, por ejemplo, es un relato de clima decadente d'annunziano sobre un hombre que sólo aspira a poseer y perfeccionar el alma de una muchacha. Este personaje está elaborado a partir de la trivialización del ideal de Superhombre intelectual colocado más allá de la mora social", en Beatriz Sarlo, El imperio de los sentimientos, Buenos Aires, Catálogos Editora, 1985, p.88.
(1906), Nietzsche contre Wagner (1906), L'Antécrist (1906), Considerations inactuelles I y II (1907), Ecce Homo (1909). En Argentina no necesariamente se leyeron en todos los casos estas primeras ediciones sino las posteriores. $Y$ podemos reconstruir esa biblioteca a partir de las ediciones actualmente disponibles en la Biblioteca de la Facultad de Filosofía y Letras de la UBA - y que figuran en la bibliografía final- A diferencia de la recepción española en que las traducciones al castellano fueron el mecanismo más común de lectura, en el Río de la Plata, por el contrario, predominaron las traducciones francesas. Varias referencias de época no dejan dudas respecto a que la recepción francesa condicionó a la local, como Rubén Darío lo advirtiera: "Si hoy Nietzsche tiene cierta influencia intelectual, es solamente después que pasó por París". 45

También en las revistas culturales locales hubo una serie de versiones traducidas de la edición francesa: en noviembre de 1899 El mercurio de América comienza a publicar Humano, demasiado humano; un año después también La revista moderna de México (vol. III, n 17-18, enero de 1900) publica gran parte de Humano, demasiado humano. En España la primera traducción fue la versión de Así hablaba Zaratustra en 1901 a cargo del misterioso Juan Fernández. ${ }^{46}$ La revista Nosotros, una publicación central del campo intelectual en construcción, entre los últimos meses de 1909 y los primeros de 1910 publica Ecce Homo en entregas. Tenemos numerosos testimonios sobre los escritos de Nietzsche que fueron leídos en el Río de la Plata. A pesar de la disponibilidad material de estos textos, es indudable que los testimonios nos demuestran que sólo el Zaratustra fue efectivamente muy leído. Ingenieros y Bunge han dejado observaciones directas que revelan la experiencia generalizada de una lectura del Zaratustra en el período de 1903 a 1905. En términos generales, conviene insistir en el marco oral de la recepción temprana y, sobre todo, en la necesidad de recordar que la dinámica de la lectura operó en un amplio espacio transtextual. ${ }^{47}$ Para comprender la radicalidad con que se debe interpretar esta situación, digamos que el predominio de la intertexualidad, las citas y los tópicos que formaban parte del circuito oral eran más importantes que la lectura directa de una obra específica.

A continuación, intentaremos indicar que el precario marco textual no impidió a los lectores-ejecutores del período temprano actualizar genuinos sentidos nietzscheanos. Para decirlo de manera metafórica, los conceptos "saltaron" por sobre las malas ediciones. Es decir que, a pesar de las débiles condiciones filoló-

45 La Revista Moderna, v. VI, n³ 3, enero de 1903.

46 Esta versión fue editada por La España moderna. Por las notables similitudes léxicas y sintácticas con el estilo de Miguel de Unamuno, se sospechaba que el gran vasco se ocultaba detrás del pseudónimo ("Juan Fernández" connota "cualquier español"). Sin embargo, según Sobejano, es más probable que el traductor fuera el krausista José de Caso, cfr. Sobejano, op. cit., pp. 67-74.

47 Cfr. Gérard Genette [1962], Palimpsestos. La literatura en segundo grado, Madrid, Taurus, 1989, pp. 9 y ss. 
gicas de la edición de Henri Albert, en la recepción tempana se activaron núcleos fundamentales del pensamiento del martillo.

\section{El anarquismo individualista}

La emergencia de un nietzcheanismo ácrata se produjo en el movimiento anarquista en torno a la intensa disputa entre anarco-individualistas y pro-organizadores.$^{48}$ La primera mención concreta a la aparición de la subcorriente del anarconietzcheanismo la registra José Ingenieros en 1898: "Un inteligente anormal, Julio Molina y Vedia, que se titula anarquista, siendo al mismo tiempo un desorientado, no tiene noción exacta de las relaciones entre el yo y el no yo; publicó en Buenos Aires, en 1895, uno o dos números de una revista que llamó La expansión individual, muchos rasgos de su mentalidad evidencian (aparte de cierta pose) alteraciones de la personalidad debida a las tres causas indicadas..." (según Ingenieros una de ellas es el egocentrismo). ${ }^{49} \mathrm{El}$ período que va de 1900 a 1910 -dentro del movimiento anarquista-, representa el dominio de la corriente organizadora y la extinción definitiva de la fracción individualista, y con ella, del subgrupo de anarco-nietzscheanos. ${ }^{50}$ Dado que el sector organizador ocupaba progresivamente los medios de prensa y, especialmente, el más importante medio de difusión del anarquismo argentino, La protesta humana, los ataques del grupo organizador contra los "superhombristas" nietzscheanos será la prolongación de la campaña más general contra la corriente individualista.

Así, por ejemplo, en una de las explicitaciones más transparentes del debate, el anarquista pro-organizador Pascual Guaglianone (La protesta, 09/03/1901) acusaba a los individualistas de varios extravíos destacando especialmente que los adherentes a las fracciones individualistas eran "todos discípulos de Nietzsche". Veamos los tres puntos principales del catálogo de defectos que

48 Entre los estudios que identifican la tendencia nietzscheana dentro del anarquismo sin profundizar los caracteres de esta formación hay que destacar a Juan Suriano, Anarquistas, op. cit. y a Leandro Delgado. Anarquismo en el novecientos rioplatense. Cultura, literatura y escritura, Montevideo, Estuario, 2017. No existe aún en Argentina una obra específica sobre el anarquismo individualista equivalente al ensayo de Diéz dedicado a España, Xavier Díez, El anarquismo individualista, Barcelona, Virus editorial, 2007. Para una evaluación razonada sobre las fuentes, desde hace poco contamos con la investigación de Lucas Domínguez Rubio (comp.), El anarquismo argentino. Bibliografía, hemerografía y fondos de archivo, Buenos Aires, CeDInCl-Anarres, 2018.

49 José Ingenieros, "Psicología colectiva”, en El mercurio de América, julio de 1898.

50 "Kropotkin fue el teórico europeo más transitado por La protesta. Entre 1904 y 1910 aparecieron 28 artículos del autor ruso, 27 de Eliseo Reclús, 10 de Enrique Malatesta, 13 de Juan Grave (en cierta forma, los tres últimos estaban emparentados teórica e ideológicamnte con Kropotkin) y sólo aparecieron tres artículos de Stirner y otros tantos de Bakunin, el mismo número que mereció Herbet Spencer", Juan Suriano, "En defensa de los oprimidos. Los anarquistas y la formación de una cultura de izquierda en Argentina", en Prismas: revista de historia intelectual, $n^{\circ} 6$, Buenos Aires, Universidad Nacional de Quilmes, 2002, p. 170.
Guaglianone señalaba en los individualistas nietzscheanos: 1. Se trataba de "charlatanes"; 2. Habían introducido "en el país una nueva sociología", un saber basado en los "factores degenerativos"; 3. Si bien invocaban a Nietzsche, "nunca conocieron la obra de éste ni siquiera por las tapas". Este testimonio de Guaglianone, despojado de su valoración negativa, puede ser confirmado por otras fuentes: en cuanto al punto 1, al menos podemos constatar que los propagandistas del "superhombrismo" tuvieron en Julio Molina y Vedia su exponente más importante, más algunos otros pocos nombres como Julio Camba y Alberto Ghiraldo. ${ }^{51}$ Este último fue quizá uno de los pocos simpatizantes del anarconietzscheanismo que alcanzó relevancia en el panorama cultural más general. Sobre el punto 2 , en efecto y como ya hemos señalado, hubo una amalgama desde el inicio de la recepción de Nietzsche con la del darwinismo, el materialismo neurofisológico y la psicopatología. Por último, con respecto al punto 3, la transmisión de ideas nietzscheanas en los círculos individualistas, en términos generales, no estuvo ligada a la lectura directa de los escritos sino a los comienzos mismos del texto oral. ${ }^{52}$ Este ataque de Guaglianone contra los individualistas nietzscheanos fue una posición programática de todo el sector organizativo triunfante en el mundo y se reitera de 1900 a 1910. Así, por ejemplo, el 12 de junio de 1904 en La protesta, Eliseo Reclús en "La pretendida decadencia anarquista" esgrime un argumento central contra los superhombristas: el anarquismo nietzscheano está comprometido con la versión darwinista "que quiere aplastar a los débiles". Este argumento es importante porque el anarquismo organizativo defendía las tesis de Priot Kropotkin sobre la sociabilidad natural del hombre y, además, adhería a la tesis evolucionista, que consideraba la solidaridad como factor clave del éxito adaptativo. ${ }^{53}$ Estas dos premisas eran negadas por el superhombrismo.

El opúsculo Hacia la vida intensa representa la elaboración más acabada de la tendencia anarconietzscheana dentro de la corriente individualista. ${ }^{54}$ El género del texto parecer ser el campo de la Sociología, con la salvedad de que se trata de un saber alternativo al de la "sociología objetiva". Desde las primeras páginas aparece el tono altisonante que se mantiene hasta el final: "afirmo que el espíritu democrático se ha vuelto una manía, necesito

51 Suriano es quien señala la adscripción de Julio Camba al anarconietzscheanismo. En 1902 fue una de las primeras víctimas de la ley de residencia; a partir de esta fecha desarrolló su actividad literaria en España, ver Juan Suriano, op. cit., p. 45.

52 Esto se aplica perfectamente al nietzscheanismo retórico del poeta $\mathrm{Al}$ mafuerte pero no a Molina y Vedia quien muestra una lectura directa de los textos.

53 Según Kropotkin, la idea de la "ayuda mutua" le fue revelada por una conferencia en 1880 a cargo del profesor Kessler. Los diferentes capítulos del libro homónimo fueron publicados en forma de artículo en septiembre y noviembre de 1890. La primera edición es de 1902, cfr. Piotr Kropotkin [1902], La ayuda mutua, Caracas, Monte Ávila editores, 2009, pp. 8 y ss.

54 Julio Molina y Vedia [1904], Hacia la vida intensa, Buenos Aires, Colihue, 2006. 
hacer el elogio de la desigualdad y la nobleza". ${ }^{55}$ Como se ve, la actualización del principio de la desigualdad es un punto central del nietzscheanismo de Molina y Vedia. Por lo demás, las citas y menciones a Nietzsche son recurrentes. La valoración de los instintos constituye la empresa de la nueva sociología subjetiva. La sociedad produce hombres domesticados. El diagnóstico es el siguiente: "La vida moderna, y en especial la de nuestras ciudades, chupa las energías del sistema nervioso de los individuos, y de aquí las formas sociales de la neurastenia: alcoholismo, prostitución, criminalidad, locura...".56 Contra esta "petrificación", "nosotros queremos que la sociedad sea, cada día más, un organismo, no embalsamado y aparente sino vivo y real, a través del cual se perciba la variada e inagotable vida de sus unidades". ${ }^{57}$ Sólo los grandes hombres y los criminales luchan contra la mediocridad del sistema capitalista. El autor denomina "Innovador" a aquel individuo que será protagonista de futuros cambios: "el Innovador no ha muerto, el hombre que ensaya nuevos modos de existencia, quizá porque heredó de remotos antepasados en toda su fuerza estos o aquellos instintos, o porque nació con un exceso de vigor en el sistema nervioso". Las referencias a la neurología son continuas. Molina y Vedia reproduce el análisis de la Genealogía de la Moral de manera resumida y a veces superponiendo neurología con genealogía. Por ejemplo, el análisis de la mala conciencia que realiza Nietzsche aparece resumido en la afirmación de que el "remordimiento" es una "asociación mental temporaria". 58

Sin lugar a dudas, el autor incorpora varios textos de Nietzsche. Sus argumentos e ideas no parecen depender de una sola obra sino que presuponen un conocimiento amplio de la filosofía del martillo. Por ejemplo, en el capítulo $\mathrm{V}$ se relaciona la categoría de salud, la memoria histórica y el olvido. El desarrollo de la civilización muestra que el olvido fortalece la vida. Pocos autores de las dos primeras décadas se refieren a las tesis anti-historicistas que Nietzsche expone en Sobre la utilidad y perjuicio de la historia para la vida. Las referencias críticas al sistema penal es otro aspecto en que se nota una lectura selectiva del filósofo alemán. Los criminales son, en realidad, seres imaginativos a los que la sociedad odia implacablemente. Las prácticas punitivas intentan frenar la expansión vital de estos incomprendidos transgresores. Por último, encontramos en Molina y Vedia un fuerte marco racialista y eugenésico. ${ }^{59}$ En este sentido, el argentino es un lector fiel a la intención nietzscheana. La sociología subjetiva parece muy interesada en fortalecer, aún más, a los hombres fuertes y, en inversa relación proporcional, exterminar a los débiles. El ataque a la beneficencia va en esta dirección. "Sustentar desvalidos,

55 Julio Molina y Vedia, op. cit., p. 29

56 Ibídem, p. 33

57 Ibídem, p. 34

58 Ibídem, p. 53

59 Para la distinción entre "racismo" y "racialismo", ver Tzvetan Todorov [1989], Nosotros y los otros, México, Siglo XXI, 1991, pp. 115 y ss. prolongar la existencia de organismos radicalmente enfermos [...]; ¡a eso llamáis beneficencia! Sólo la fuerza de la costumbre, sólo nuestro ineludible cristianismo nos impide colocar vuestra caridad, como sería justo, en la categoría de los crímenes más odiosos, de la peores llagas de vuestra sociedad".60 En este tipo de configuración es que notamos que opera la fuerza ilocucionaria de los conceptos nietzscheanos.

En resumen, diremos que el anarconietzscheanismo, que floreció intensamente en el período 1897-1900 en los círculos anarquistas del mundo (por lo menos de España, Italia, Francia, Estados Unidos, Argentina y Uruguay) fue, acaso, la primera interpretación del pensamiento de Nietzsche fuera de los países de lengua alemana. ${ }^{61}$ El núcleo de esta versión de nietzscheanismo incorporó la tesis "egoísta" de Max Stirner, intensificando de esta manera el individualismo, y además estuvo impregnada de dudosos saberes como el darwinismo social y la eugenesia, entre otros. Nótese que en esta amalgama ya se encuentra in nuce el conjunto de los otros operadores discursivos. Una última pregunta de orden semiótico: ¿acaso los anarconietzscheanos no "usaron" la obra del filósofo con la libérrima voluntad de exceder a Nietzsche o de "sobre-interpretarlo"? Estimamos que no. Más bien pensamos que los anarquistas individualistas interpretaron el intertexto stirneriano y actualizaron los conceptos nietzscheanos de desigualdad y superhombre. ${ }^{62}$

\section{El darwnismo social}

En 1853, unos años antes de la publicación de El origen de las especies, Arthur de Gobineau dio a conocer su Ensayo sobre la desigualdad de las razas humanas. Este libro sería el comienzo de una serie de teorías raciales y racistas que culminaría en la legitimación del imperialismo por la ideología del darwinismo social. El texto de Gobineau anticipó un tipo de literatura pesimista que comenzaba a conectar cierta fenomenología de la decadencia con la lucha entre las razas y los efectos negativos del mestizaje. ${ }^{63}$ Con respecto a la participación del darwinismo propiamente dicho en esta ideología imperialista, diremos que hubo dos posiciones muy definidas y antagónicas: el darwinismo social que adhirió sin reservas a la ideología de la superioridad racial y a la justificación del exterminio de las "razas inferiores"

60 Ibídem, p. 69.

61 Es notable que este hecho no ha sido reconocido suficientemente por los estudios de la recepción de la filosofía de Nietzsche en todo el mundo.

62 Ya se ha establecido de manera contundente la importancia de Max Stirner para la filosofía nietzscheana, ver la bibliografía en la entrada "Stirner" en el Diccionario Nietzsche, op. cit., p. 492. Pero, además, creemos que la concreción histórica de los anarconietzscheanos muestra la fuerza ilocutiva del intertexto stirneriano.

63 Ver el excelente análisis de Hannah Arendt [1948], Los orígenes del totalitarismo, vol.2, Barcelona, Planeta, 1994, capítulo 6. 
en virtud del principio de "la supervivencia del más apto" y, por otro lado, el evolucionismo solidarista que sostuvo el valor de la ayuda mutua de los distintos grupos (colonias de animales o comunidades humanas) para sobrevivir. En cuanto a la primera posición podemos nombrar a Francis Galton, Ernst Haeckel, Charles Michel, Thomas Huxley, Benjamin Kidd, John B Crozier, Karl Pearson y Charles Harvey; ${ }^{64}$ con distintos énfasis, todos ellos abogaron por el control de la natalidad y la eugenesia y afirmaron la inevitable extinción de las "razas inferiores". En la posición opuesta se encuentran la línea solidarista de Piotr Kropotkin que en Latinoamérica esgrimirá el libertario peruano Manuel González Prada contra el racismo. 65

En los comienzos del siglo $\mathrm{XX}$, dentro de la tendencia social-darwinista, podríamos mencionar a Leopoldo Lugones y José Ingenieros en sus años juveniles. Sin embargo, contra todos los pronósticos, casi no encontramos referencias a Nietzsche y el nietzscheanismo en la revista que ambos editaron desde 1897, La Montaña. ${ }^{66}$ A pesar del fuerte contenido antiburgués y juvenilista avant-la-lettre, los jóvenes Ingenieros y Lugones no parece inclinados por el nietzscheanismo. ${ }^{67}$ En la reseña "El individuo y la sociedad", ${ }^{68}$ sobre el libro del anarquista organizador Juan Grave, Ingenieros destaca que comparte en gran parte las ideas del autor y se pronuncia en contra de "las exageraciones ultra-individualistas que tantos estragos han hecho últimamente en las filas del anarquismo, motivando una escisión profunda entre los anarquistas individualistas y los anarquistas comunistas". Los partidarios de aquella fracción "han saturado de un mal entendido individualismo hasta el extremo de forjar e idolatrar ciegamente el nuevo fetiche entidad-individuo". Sabemos que en otros artículos contemporáneos los dos escritores se pronuncian contra el nietzscheanismo y, en particular, contra el anarconietzscheanismo.

Hay que esperar hasta las Crónicas ${ }^{69}$ para encontrar la novedosa interferencia de las ideas nietzscheanas en el pensamiento de Ingenieros. En este horizonte de 1904 los componentes principales de su discurso positivista serán la psicopatología, el racialismo y el idealismo elitista, ahora en conexión con su nietzscheanismo. El hecho de que estos elementos sean "composibles" en una obra como Crónicas significa que el desarrollo posterior del pensamiento de Ingenieros, incluyendo su etapa "eticista-litista",

64 Ibídem, p. 244, nota 55

65 Manuel González Prada, "Nuestros indios", en Antología de textos, México, Ediciones de la Secretaría de Educación Pública, 1943, p. 167 y ss.

66 Solo en el último número, La Montaña, $n^{\circ} 12$, del 15 de septiembre de 1897 aparece una noticia bibliográfica de La Revue Blanche en donde se menciona el Nietzsche contra Wagner.

67 Horacio Tarcus ha arrojado luz sobre la peculiar ideología de La montaña al señalar que sus jóvenes editores compartían el socialismo revolucionario de Jean Allemane (1843-1935). Horacio Tarcus, op. cit., pp. 416-428.

68 La Montaña, $n^{\circ} 8,1997$

69 José Ingenieros, Crónicas de Viaje, Buenos Aires, Ediciones Rosso, 1920. Ver Rodrigo Páez Canosa. "El culto a la risa: el joven Ingenieros y Nietzsche", en Instantes y azares, $n^{\circ} 1,2001, p p$. 151-167. podría interpretarse como un conjunto de componentes co-existentes ya desde su fase inicial. ${ }^{70}$ Seguiremos la articulación entre biologicismo, vitalismo y nietzscheanismo en los próximos párrafos. $^{71}$

Ya en el banquete de homenaje a José León Pagano en 1903, Ingenieros explica su adhesión a las ideas nietzscheanas. Luego de reconocer que amó "intensamente" a la "multitud", aludiendo a su antigua filiación socialista, comenta que se desilusionó por "su alma infantil e ineducada". Entonces, "...viendo en ella una turba de burgueses pobres no basta la pobreza para hacerlos mejores que los plebeyos ricos sintióse mi espíritu arrastrado sobre la huella de tu dominador; la necesidad de sentimientos mejores, de más elevadas aspiraciones, me explicó el enigma de Nietzsche". ${ }^{72}$ Esta crisis ideológica no debe subestimarse. De un socialismo romántico y diletante, como fue su temprano posicionamiento, Ingenieros pasó a confiar en las "minorías activas" que conducen a las "informes multitudes". El nietzscheanismo parece ser la forma más cruda de exposición de este aritocraticismo de "dominadores".

En un texto posterior (1919) que se presenta como prólogo de las Crónicas, y a manera de retractación, Ingenieros reconocerá que el nietzscheanismo fue "la única moda intelectual a que fui sensible en mi juventud"; si bien, agrega reafirmando su cientificismo de madurez, "no ignoré que la exaltada prosa de Nietzsche era un producto de su alienación mental". ${ }^{73}$ Poco antes de emprender el viaje que dará motivo a sus Crónicas, el escritor expresa cabalmente su pathos vitalista: "Todo movimiento es bello. Toda acción es fecunda. Toda fuerza es admirable. [...] Como buscamos el movimiento en la Naturaleza debemos buscarlo en la Vida, que es acción, diversa e innumerable, pero incesante".74 En el texto "Jesús y Federico", de las Crónicas, se articulan el biologicismo, el vitalismo y el nietzscheanismo: "El loco Jesús fue apóstol de una enfermiza decadencia, astro crepuscular ante una

70 Oscar Terán sostiene que el nietzscheanismo de Ingenieros se prolongó parcialmente a lo largo del período que comienza con El hombre mediocre. Oscar Terán, "José Ingenieros o la voluntad de saber", en En busca de la ideología argentina, Buenos Aires, Catálogos, 1986, p. 71. En efecto, el aristocraticismo será un componente importante en el Ingenieros posterior. Incluso en la primera edición de El hombre mediocre los componentes elitistas más crudos fueron luego suavizados por su autor. Alejandra Mailhe, "'El laberinto de la soledad' del genio, o las paradojas de El Hombre mediocre", en Varia Historia, vol. 29, n 49, enero/abril 2013.

71 Para una interpretación distinta a nuestra hermenéutica de la sospecha, ver también Rodrigo Páez Canosa, op. cit.

72 Citado en Dardo Cúneo, El romanticismo político, Buenos Aires, Transición, 1955, p. 77.

73 El párrafo completo del prólogo es el siguiente: "Subjetivo el placer, en cuanto evoca horas de una juventud que recuerdo sin remordimientos; impersonal, la sorpresa, pues no me reconozco ya en ciertas páginas afectadas de egotismo y literatura. He descubierto algunos rastros de la única moda intelectual a que fui sensible en mi juventud; y es curioso que, al padecerla, no ignoré que la exaltada prosa de Nietzsche era un producto de su alienación mental".

74 "Al partir..." discurso pronunciado en 1904 e incluido en José Ingenieros, Crónicas de Viaje, op. cit., pp. 295-300. 
larga noche de la moral humana. El loco Nietzsche cree cerrar el triste paréntesis presagiando auroras nuevas, astro de un vigoroso amanecer". ${ }^{75}$ La antítesis entre el cristianismo biológicamente degenerado y la alternativa vitalista nietzscheana es la oposición estructural que un constate anticlerical, como Ingenieros, descubre en todo su dramatismo: "La moral cristiana es clorófica, compasible. Induce a prolongar las existencias inferiores con limosnas de absurdo altruismo: rebajan al que las da y ofenden al que las recibe. Se ha convenido en llamarla moral; es, indudablemente, un buen negocio para los cobardes". En cambio, "Nietzsche es plenitud vigorosa [...] induce a perseguir el único derecho incontrastable: la conciencia de la propia fuerza" ${ }^{76}$ No pueden quedar dudas sobre el fuerte compromiso entre biologicismo y recepción de las ideas nietzscheanas: "...la moral de Federico puede armonizarse con las leyes fundamentales de la biología, es propicia al seleccionamiento y aspira a que la evolución de las vivas sobrepase al hombre, que es actualmente su forma superior". Notamos que el discurso evolucionista está operando junto con el nietzscheanismo.

El racialismo de las Crónicas de Ingenieros se comprueba en el rol central de las nociones de raza, evolución, vida y energía. Es más: el radicalismo de su propuesta, en términos de Todorov, se desplaza claramente del racialismo al racismo. ${ }^{77}$ Es decir, de la consideración de teorías sobre la superioridad racial de ciertas razas se pasa a las propuestas prácticas de exterminio o bien, en el caso de Ingenieros, a la aceptación y justificación de distintas formas del genocidio. En su visita a la isla de San Vicente del archipiélago de Cabo Verde, Ingenieros se refiere a la raza negra como "una oprobiosa escoria de la especie humana". 78 Señala el viajero: "la solidaridad humana resulta aquí una preocupación lírica e irracional. Los 'derechos del hombre' son legítimos para los que han alcanzado una misma etapa de evolución biológica...". Por esta razón la selección natural se comporta como un verdugo lógico y estricto: "Semejantes hombres no pueden sobrevivir en la lucha por la vida. La selección natural, inviolable a la larga para el hombre como para los demás animales, acabará con ellos toda vez que se encuentren frente a frente con las razas blanca", "cuanto se haga en pro de las razas inferiores es anticientífico".79

Para ilustrar el contorno biográfico de este clima intelectual conviene traer a colación que durante su viaje Ingenieros ofició de secretario privado nada menos que de Julio Argentino Roca. La significación política de este hecho no es menor. Por eso, como era previsible, Manuel Gálvez, su constante adversario intelectual, se esforzó por registrar la situación. Al parecer, a fines de 1905 el director de la revista Ideas encuentra a Ingenieros escol-

$\begin{array}{ll}75 & \text { Ibídem, p. } 123 . \\ 76 & \text { Ibídem, p. } 126 . \\ 77 & \text { Ver Tzvetan Todorov, op. cit., pp. } 115 \text { y ss. } \\ 78 & \text { Ibídem, p. } 190 . \\ 79 & \text { Ibídem, p. } 193 .\end{array}$

tando al expresidente. En el intercambio de saludos el fumista habría expresado: "Aquí me tenés. He transigido con todo. Con el militarismo... Sólo me falta hacerme clerical...". 80 Una segunda anécdota nos ilustra específicamente el modo en que el efecto nietzcheano se experimentaba en la vida pública y privada de los porteños. Según Gálvez, Alberto Gerchunoff había publicado en El heraldo un "tremendo artículo contra Ingenieros en forma de cuento": un individuo llamado X Rodríguez era un médico con mentalidad de tendero que, siendo mediocre, se creía uno de esos "superhombres que escupen contra el pueblo". Ingenieros se enfureció con esta sátira sin duda perspicaz y certera de sus juegos y buscó al autor con ánimos de un desquite cuerpo a cuerpo. El episodio fue célebre entre "unas cuantas mesas de La Brasileña y en las redacciones de dos o tres diarios de mala muerte", y terminó en una reconciliación. ${ }^{81}$

\section{Materialismo e instintivismo nietzscheanos}

En el capítulo "El paradigma histórico del instinto nietzscheano" de su excelente obra Freud y Nietzsche, Paul Laurent Assoun ha llamado la atención sobre el lugar central que ocupa la noción de instinto en la obra de Nietzsche. ${ }^{82}$ Pero Assoun no indaga las fuentes neurológicas de la inspiración nietzscheana. El mérito de recuperar este hilo conductor le pertenece a Marcel Gauchet. En el breve ensayo El inconsciente cerebral, el investigador reconstruye los hitos de la tradición subterránea del inconsciente neurológico, desde T. Laycock hasta W. Griesinger (a quien Freud leyó "con atención extrema"). ${ }^{83}$ Según Gauchet, "es un hecho que Nietzsche utilizó a fondo los trabajos de algunos de nuestros neurofisiólogos". ${ }^{84}$ Esta tradición se basaba en las tesis del automatismo psíquico, la memoria orgánica y la sinestesia. La teoría de la "cerebración inconsciente" afirmaba la inexistencia de una

80 Manuel Gálvez, Amigos y maestros de mi juventud, Buenos Aires, Hachette, 1961, p. 141

81 Ibídem, pp. 137-138.

82 Según el estudioso francés, una de las fuentes más importantes de la concepción nietzscheana del instinto fue la teoría del Kunsttrieb tal como la desarrollaron Schiller y Hölderlin. Assoun no olvida el carácter naturalista del instintivismo nietzscheano puesto que -señala- la influencia de la teoría del Lebenstrieb de Wagner se inspira en el sensualismo feuerbachiano. Para éste el Lebenstrieb se basa de la primacía de la sensibilidad (Sinnlicchkeit). Respecto del valor naturalista de la concepción instintivista de Nietzsche, Assoun señala que proviene de "la revolución darwiniana, última etapa de la génesis compleja que lleva a la idea de instinto hasta donde Nietzsche y Freud la reciben", Paul-Laurent Assoun [1980], Freud y Nietzsche, México, FCE, 1984, p. 94, nota 48.

83 Gauchet define al principio de su obra tres vertientes genealógicas del inconsciente: el inconsciente filosófico (el del romanticismo alemán, según el autor "sobre-estimado" como fuente), el inconsciente hereditario y el inconsciente neurológico. Gauchet se concentra en éste último: "a través del inconsciente cerebral yo quisiera demostrar que el rol angular, tradicionalmente reconocido a la voluntad en la economía del funcionamiento subjetivo, fue puesto en duda y subvertido", Marcel Gauchet [1992], El inconsciente cerebral, Buenos Aires, Nueva Visión, 1994, p. 22. 
centralización de las decisiones. La inteligencia se manifestaba como una continuidad funcional del sistema nervioso, por eso también la médula espinal tiene capacidad operativa tanto como el cerebro. Nietzsche recogió gran parte de las tesis neurofisiológicas en su crítica a la subjetividad. No cabe duda de que la noción de "vida" para el filósofo está fuertemente asociada a la de "instintos" y que éstos constituyen una pluralidad constitutiva.

Por lo general, en una larga tradición de la historia de la filosofía se suele separar el materialismo mecanicista del vitalismo espiritualista. ${ }^{85}$ La crisis del mecanicismo en torno al 1890, impulsó a ciertas corrientes materialistas a posiciones energetistas. Una serie de nombres, como Ludwig Büchner, Whilhem Ostwald, Félix Le Dantec, Ernst Mach, Richard Averanius y Hans Driesch, representan parte de esta compleja encrucijada en que materialismo no mecanicista y vitalismo se solapan. Ahora bien, en este marco instintivista-vitalista resulta pertinente saber en qué medida la cultura científica rioplatense del novecientos fue receptiva al instintivismo nietzscheano, en particular el paradigma positivista, tanto en sus campos de especialización científica como en la esfera cultural más vasta.

La articulación entre nietzscheanismo y materialismo más sistemática, dentro la recepción temprana en el Río de la Plata, fue elaborada por el literato uruguayo Carlos Reyles en su obra La muerte del cisne (1910). ${ }^{86}$ Este ensayo sistematiza la oposición más frontal al idealismo modernista en general y a la filosofía humanista de Rodó en particular. Quizá pueda sorprender el hecho de que Carlos Reyles fuera un estanciero. Esto no va en detrimento de su nietzscheanismo ni de su materialismo cínico. Pero sí puede parecer insólita su simpatía por Karl Marx. La boutade de Zum Felde resume el problema: "Marx en Wall Street". ${ }^{87}$ Podríamos decir que ningún otro intelectual estaba más preparado para recibir la filosofía nietzscheana de manera tan hospitalaria. Asimismo su adhesión al naturalismo de Zola y al decadentismo de D’Anunnzio determinó que la posición de Reyles se moldeara con componentes iconoclastas muy radicales.

Para el escritor uruguayo, el fenómeno del "instinto vital" es "el travieso mago que en la filosofía nietzscheana crea las ilusiones". 88 Se trata de comprobar si la "agonía de lo divino", es decir, el "espejismo" de las creencias religiosas ya no es "necesario a la vida". ${ }^{89}$ La fuerza, la energía y la vida se oponen al espíritu y al ideal. En el capítulo 3 de esta parte I, Reyles recrea ideas de la Genealogía de la Moral. La historia demuestra que los valores sobreviven únicamente como "códigos de los grupos dominan-

85 Cfr. Ricaurte Soler, El positivismo argentino, Buenos Aires, Paidós, 1968, pp. 112 y ss.

86 Carlos Reyles, La muerte del cisne, París, Ollendor, 1910.

87 Alberto Zum Felde, Índice crítico de la literatura hispanoamericana, México, Guarania, 1954, p. 284

88 Carlos Reyles, op. cit., p. 11.

89 Ibídem, p. 21. tes", pero su existencia es relativa a la permanencia de esos pueblos, "de donde se infiere que no existe una moral única, sino mil morales". 90 Y, siguiendo a Nietzsche en su genealogía-filológica de las virtudes guerreras, lo que "generalmente se llama injusticia es el resultado de muchas virtudes anteriores, y lo que inspira nuestra ilusa piedad". ${ }^{91}$ En el capítulo 5 se exponen matices de la concepción bélica-agonal de la "lucha y la dominación". En el capítulo 6 se desenmascara la psicología del sacerdote: las luchas entre la reacción religiosa y el anticlericalismo, que "muestran hasta qué punto los principios activos de la fuerza, aunque disfrazados por ideales máscaras, ordenan las maniobras de las huestes espirituales para la conquista y la sumisión del mundo".92 La fuerza es el motor que detrás de las ideas lleva adelante todo proceso de acción de manera violenta. "Y al modo de la idea, instintos, pasiones y sentimientos nacen o mueren, crecen o menguan, dominan o caen en esclavitud gracias a las mil formas de selección que reviste el juego universal de la fuerza". ${ }^{93}$ Está presente en esta reconstrucción el nivel fisiológico instintivista que el propio Nietzsche compartía con la corriente materialista del "inconsciente cerebral".

En resumen, los puntos importantes de la lectura del filósofo-estanciero son los siguientes: en el plano cultural-religioso se asume la destructividad liberadora de la filosofía del martillo como acto de desenmascaramiento radical, en el plano político se acepta el aristocraticismo y el anti-igualitarismo y en el plano científico Reyles elabora su versión instintivista-materialista dentro del paradigma racialista.

\section{Pedagogía social de Raquel Caamaña}

Tomaremos otro caso en que los conceptos nietzscheanos se cruzan con la pedagogía anarquista y la eugenesia. El historiador Daniel de Lucía, en una serie de artículos, es quien más ha profundizado en la figura de Raquel Caamaña. ${ }^{94}$ Mónica Cragnolini fue la primera en advertir su importancia para la recepción tempana de Nietzsche..$^{95}$ Incluimos a Caamaña en la corriente librepensadora y en el socialismo, cercana al círculo de Alicia Moreau. Podemos resumir su pensamiento en la siguiente caracterización. Su formación intelectual comienza con Mary O'Graham en el Escuela Normal de La Plata; las doctrinas educativas de esta pe-

$90 \quad$ Ibídem, p. 18.

91 Ibídem, p. 20.

92 Ibídem, pp. 32-33.

93 Ibídem, p. 30.

94 Daniel De Lucía, "El partido socialista y la enseñanza de la moral (18901936)", en Boletín del FEPAI, $n^{\circ} 20$, 2do semestre de 1992; "El movimiento librepensador y la cuestión femenina (1895-1920)", en Desmemoria, $n^{\circ} 16,1997$ y "Los socialistas y la infancia", en Todo es historia, $n^{\circ} 355$, febrero de 1997.

95 "Nietzsche en la Argentina...", op. cit., pp. 115 y ss. 
dagoga reflejan la vulgata normalista, comteana y spenceriana. El discurso "feminista" que Caamaña postula la igualdad entre el hombre y la mujer por medio de la "co-educación", al tiempo que, coincidiendo con los grupos feministas en los que participa, señala que el rol constitutivo de la mujer sigue siendo la maternidad. ${ }^{96}$ La emancipación de la mujer que defiende Caamaña es muy restringida porque no objeta el rol tradicional de la maternidad. El instinto de procreación es elevado a la condición de sagrado.

Se advierte su vitalismo nietzscheano en el ataque a las "mentiras vitales" que restan valor a la vida. La degeneración y todos los males culturales y sanitarios se originan por la debilitación de la vida. Probablemente, el nietzscheanismo de Caamaña proviene de la lectura del ensayo de Reyles. Por otro lado, la pedagoga se muestra como una laica moderada: no es anticlerical, pero es partidaria acérrima de la educación popular y pública. La religión es aceptada en tanto no niegue ni disminuya el valor de la vida.

La importancia de la eugenesia en el pensamiento de Caamaña es decisiva y además se corresponde perfectamente con el vitalismo nietzscheano (se trata de la conexión entre anarquismo, eugenesia y nietzscheanismo que ya destacamos). Su línea de inspiración, incluyendo la "co-educación", proviene de las ideas neomalthusianas de Paul Robin (1837-1912). ${ }^{97}$ La pedagoga propone, además de un genérico ideal educativo normalista, una política profiláctica, higienista y eugenésica. Este rasgo, más que ningún otro, nos indica hasta qué punto el nietzscheanismo fue funcional al positivismo. Caamaña es una liberal reformista: nunca es visible su apelación a los sectores subalternos como sujetos. En cambio, su crítica siempre se expresa en consejos a la "aristocracia" para que se vuelva ilustrada y no degenere en "plutocracia". ${ }^{98}$

El compromiso de Caamaña con las ideas vitalistas es claro: "El elemento activo de la conducta es la expansión de la vida. La superioridad del espíritu se basa en que éste realiza el máximum de intensidad-extensiva, de fuerza dominante nietzscheana". ${ }^{99}$ Luego de citar y comentar algunos pasajes del Zaratustra, Caamaña concluye "Y es 'ese más alto grado de voluntad de potencia' lo que debe dirigir la procreación humana. Verdad en la que germina la del arribo del super-hombre por consciente y voluntaria construcción interna...".100 El punto central de la eugenesia de Caamaña es la "higiene integral": "la procreación de seres sanos y

96 Sobre este feminismo, ver Marcela Nari, Políticas de maternidad y maternalismo político, Buenos Aires, Biblos, 2004.

97 Tina Tomáis [1978], Breviario del pensamiento educativo libertario Cali, Carvajal, 1988, pp. 176 y ss.

98 "El deber de la aristocracia es servir al pueblo de vida sana y feliz"..."pero cuando se trata de una plutocracia -como desgraciadamente en nuestra Argentina- esa clase colocada a mayor altura sirve tan sólo para difundir, aumentados, sus defectos." Raquel Caamaña, Pedagogía social, Buenos Aires, La cultura argentina, 1916, pp. 76-78.

Raquel Caamaña, op. cit., p. 56.

100 Ibídem, p. 57 fuertes es el primer deber individual" ${ }^{101}$ Notemos, por otra parte, que las ideas educativas de Caamaña oscilan entre la pedagogía ácrata y el proyecto de Ricardo Rojas. ${ }^{102}$ Ésta, podríamos decir, es la tensión central del pensamiento pedagógico de Caamaña: su intento de síntesis del programa positivista ácrata con el espiritualismo nacionalista. Una tercera vertiente de interés para nuestro análisis se refiere a la cuestión feminista. Es casi seguro que Caamaña adhirió a la versión del feminismo paternalista-romántico y pro-nietzscheano de Daniel Leuseur, autora de una novela muy leída en Francia y en el Río de la Plata, La partidaria de Nietzsche (1908). ${ }^{103}$

Destaquemos, una vez más, las líneas ideológicas que se cruzan en el nietzscheanismo de Caamaña: un discurso paternalista sobre lo femenino, el anti-igualitarismo, la eugenesia y el vitalismo.

\section{Conclusiones: el efecto político del nietzscheanismo}

Comenzamos realizando algunas observaciones sobre el subgénero de la historia de la recepción. Este primer bosquejo del microsistema de la recepción temprana nos ha permitido seguir el hilo conductor del principio de la desigualdad humana como efecto reconocible en las versiones locales del nietzscheanismo rioplatense. Ahora conviene establecer qué lugar tuvo esta corriente en el seno de la hegemonía del positivismo. A primera vista, como hemos visto, la filosofía nietzscheana era reivindicada sólo por ciertas minorías de la elite o bien por los grupos marginales de la corriente ácrata del individualismo. En cambio, los "intelectuales faros" de la elite, como José Enrique Rodó o Rubén Darío, mantuvieron un rechazo genérico contra el nietzscheanismo. ${ }^{104}$ Pero, más allá de la impugnación por gran parte de los intelectuales positivistas, hemos notado, al mismo tiempo, una am-

\section{Ibídem, p. 137.}

102 Daniel De Lucía, "El partido socialista..., op. cit..

103 Daniel Lesueur, Nietzschéene, Paris, Plon, 1908. La versión local: La partidaria de Nietzsche, Buenos Aires, Biblioteca La Nación, 1909.

104 Respecto de Rubén Darío, ver. Noel Rivas Bravo, 'Un 'raro' excluido de Los raros", en Alfonso García Morales (ed.), Rubén Darío. Estudios en el centenario de Los raros y Prosas profanas, Sevilla, Universidad de Sevilla, 1998, pp. 69-84. Rodó es contundente: "El anti-igualitarismo de Nietzsche ha llevado a su poderosa reivindicación de los derechos que él considera implícitos en las superioridades humanas un abominable, un reaccionario espíritu; puesto que, negando toda franqueza, toda piedad, pone en el corazón del superhombre a quien endiosa un menosprecio satánico para los desheredados y los débiles; legitima en los privilegiados de la voluntad y de la fuerza el ministerio del verdugo; y con lógica resolución llega, en último término, a afirmar que la sociedad no existe para sí sino para sus elegidos [...] Por fortuna, mientras exista en el mundo la posibilidad de disponer dos trozos de madera en forma de cruz es decir, siempre, $\mathrm{i}$ la humanidad seguirá creyendo que es el amor el fundamento de todo orden estable y que la superioridad jerárquica en el orden estable no debe ser sino una superior capacidad de amar!", en "Ariel", en Obras Completas, Buenos Aires, Claridad, 1956, p.188. 
plia penetración del nietzscheanismo en el sistema cultural. De manera que la presencia del filósofo no fue meramente marginal ni ajena al corazón de la hegemonía positivista. La infatigable lucha de Joaquín V. González por la eugenesia, por ejemplo, nos muestra hasta qué punto los motivos nietzscheanos coincidían con el racialismo del reformismo liberal. ${ }^{105}$ Debemos, por tanto, desentrañar una "afinidad electiva" entre cierta práctica científica y la filosofía experimental del alemán.

Una respuesta provisoria a la anterior cuestión podría formularse en los términos siguientes. El humanismo renaniano fue el factor aglutinante de las distintas vertientes del positivismo. Resulta instructivo observar cómo aquella tendencia podía unificar un programa común para las distintas prácticas de la elite. Ahora bien, el nietzscheanismo compartía un fondo común con las ideas de Ernest Renan. La convergencia entre ambas filosofías se advierte en dos aspectos centrales: el elitismo y la importancia de la eugenesia. A pesar de que el humanismo renaniano ofrecía un marco de moderación muy valorado por la oligarquía liberal, en algunos tramos de sus escritos sorprende el grado de radicalización racialista o, más bien, racista de su proyecto. En los Dialogues et fragments philosophiques el autor francés concebiría una utopía de una dictadura de sabios que se propone la creación de una nueva raza. ${ }^{106}$ Este énfasis antidemocrático pensado desde parámetros racialistas coincide perfectamente con el proyecto nietzscheano. Un testimonio de Rubén Darío confirma esta convergencia entre ambos pensadores, a la vez que explica la preferencia que tuvo la intelectualidad por el francés: "Yo, por mí, confieso que he encontrado en Renán un Nietzsche avant la lettre, morigerado y con razón [...] el famoso Anticristo alemán se contiene en la filosofía del francés. Con la diferencia de que el 'buen tirano' es preferible al aplastante superhombre y el banco de la meditación a la camisa de fuerza". ${ }^{107}$

Quizá el mayor aporte que proporciona el estudio de la recepción temprana se refiere a un punto hermenéutico fundamental:

105 Eduardo Zimmermann, op. cit., pp. 112 y ss. Para la constitución del campo eugénico argentino, ver Marisa A. Miranda, "Matrimonio y procreación en la ortodoxia eugénica argentina", en Cuadernos del CISH, n¹718, 2005, pp. 151-178. El eugenista chileno Hans Betzhold, compenetrado con la eugenesia del nacionalsocialismo reconocía el aporte de Nietzsche a la disciplina y avizoraba un próximo "Superhombre chileno", cfr. Hans Betzhold Hess, Eugenesia, Santiago de Chile, Zig-Zag, 1942, citado por Marcelo Javier Sánchez Delgado, Chile y Argentina en el escenario eugénico de la primera mitad del Siglo XX, Tesis de Doctorado, Santiago de Chile, Universidad de Chile, 2015, p. 303 y ss. Sobrela eugenesia en Latinoamérica, Nancy Stepan ha señalado el carácter más moderado de este saber con respecto a sus análogos europeos. La eugenesia en nuestra área estuvo al servicio de los nuevos Estados nacionales y sus políticas de integración, cfr. Nancy Leys Stepan, The hours of eugenics: race, gender and nation in Latin America, Ithaca,Cornell University Press, 1991.

106 Ernest Renan, Dialogues et fragments philosophiques, Paris, Calmann Lévy, 1876, pp. 100 y ss.

107 Rubén Darío. "Las fiestas de Renán", en La Nación, 20 de octubre de 1903, citado por Günther Schmigalle, "Darío, lector de Nietzsche", en Anales de Literatura Hispanoamericana, $n{ }^{\circ}$ 47, 2018, pp. 132-133. la emergencia del nietzscheanismo en nuestra región, así como en la Alemania guillermina, en la República de Weimar o en el III Reich, muestra que los conceptos nietzscheanos no se distorsionan por una "ideologización" exterior o contextual como interpretan Diego Sánchez Meca, Killian Biescas y, en cierta medida, Steven Aschheim. ${ }^{108}$ No se trata de que los usos políticos adulteren la pureza de un texto o las intenciones puramente filosóficas de Nietzsche. La "hermenéutica de la inocencia" parece dominar los estudios nietzscheanos. Para tomar un solo ejemplo, en la entrada "Transmisión hereditaria" (Vererbung) del lexicón de Christian Niemeyer luego de citar la afirmación de Nietzsche "Los alemanes deberían criar una casta dominante", la especialista comenta que ésta y otras declaraciones "fueron malinterpretadas en un sentido racista durante la época del nacionalsocialismo". ${ }^{109}$ No se comprende cómo se podría "malinterpretar" un pasaje tan diáfano del filósofo alemán. Por el contrario, como señala Ernst Nolte, estudioso insospechable de tendencias izquierdistas, "probablemente resulte más correcto decir que el nacionalsocialismo se quedó rezagado" con respecto al plan nietzscheano sobre la guerra, el "partido de la vida" y la "aniquilación".110

Nuestro recorrido indica que la fuerza ilocutiva de los conceptos nietzscheanos se concretiza en distintas versiones significativas. Es decir que estas versiones del nietzscheanismo, en cierta forma, están "previstas" por la intención del texto. La concreción de una interpretación, pues, forma parte del despliegue histórico del proyecto nietzscheano. Incluso allí donde podemos detectar un "uso aberrante" de la intención del texto, el historiador debe explicar que tal versión desborda los sentidos de la obra del filósofo. Sin embargo, estos "usos aberrantes" son más bien excepcionales. En rigor, debemos considerar un principio básico de la hermeneútica de la sospecha: un texto invocado en cierta acción está relacionado con ésta hasta que se demuestre lo contrario. $\mathrm{Ni}$ los nacionalistas de 1914 en Alemania ni los nazis poco después invocaron la obra de Francisco de Asís para justificar sus acciones sino el nombre de Friedrich Nietzsche."11

Respecto al biologicismo y su relación estructural con el pensar

108 Cfr. Diego Sánchez Meca, "Introducción general a la edición española de los Fragmentos Póstumos", en Friedrich Nietzsche, Fragmentos Póstumos, 4 vols., Madrid, Tecnos, 2006-2010, pp. 21 y ss.

109 Christian Niemeyer (ed.), op. cit., p. 510. La entrada pertenece a la investigadora Pia Daniela Schmücker.

110 Ernst Nolte [1990], Nietzsche y el nietzscheanismo, Madrid, Alianza, 1995, pp. 206 y ss.

111 Luego de admitir la existencia de "malas lecturas", Martin Jay agrega: “... la potencialidad para las distorsiones específicas que se producen puede considerarse como latente en el texto original. Así, si bien puede ser cuestionable cargar a Marx con la responsabilidad por el Archipiélago Gulag o culpar a Nietzsche por Auschwitz, también es cierto que sus escritos podrían ser mal leídos como justificaciones de estos horrores, de un modo que, digamos, los de John Stuart Mill o los de Alexis Tocqueville no lo podrían", Martin Jay [1988], "¿Debería la historia intelectual tomar un giro lingüístico? Reflexiones sobre el debate Habermas-Gadamer?", en Socialismo fin-de-siècle, Buenos Aires, Nueva Visión, 1990, p. 46 . 
dionisíaco, ya Herbert Schnädelbach había planteado una perspectiva genealógica plausible: "Sin el biologicismo no se puede comprender el éxito de Nietzsche en Alemania, o el impacto de Der Untergang des Abendlandes de Oswald Spengler y, muy en especial, el populismo (völkisch) de la ideología racista de los filósofos nazis".122 Es sabido, que la magistral interpretación de Heidegger representa un intento de des-biologizar la filosofía de Nietzsche. Específicamente el mago de Messkirch propone una lectura ontológica contra la "vulgar" lectura racista de Alfred Bäumler. Sin embargo, de nuevo vemos que los conceptos siguen operando con efectos políticos concretos ya que el propio pensar heideggeriano está implicado en el movimiento nacionalsocialista. ${ }^{113}$ De manera que el distanciamiento de la interpretación bilogicista no pone a salvo a la ontología fundamental del compromiso práctico con el hitlerismo. Incluso en el nietzschenismo post-68 encontramos una ambivalencia respecto al problema del racismo. Por un lado, el nietzscheanismo indudable de Deleuze nunca ha ocultado su fidelidad al "hilo conductor del cuerpo". En sus escritos no se recupera el biologicismo "clásico" pero sí se preserva la dimensión del cuerpo y los instintos. En el seminario Defender la sociedad, Michel Foucault emprendió la genealogía del racismo en la constitución misma de la "biopolítica". En la última lección se desplaza hacia los siglos XIX y XX. Allí destaca la ubicuidad del racismo, su relación con el evolucionismo y con las prácticas que serán capturadas por el Estado. Por último, Foucault se refiere al racismo del nacionalsocialismo. Es decir, a la peculiaridad de que el Estado nazi fue "racista, homicida y suicida". Sin embargo, Foucault notoriamente omite cualquier alusión al rol estratégico del pensar nietzscheano en la trama de la biopolítica. Esta omisión es realmente significativa porque no problematiza una cuestión que el solo nombre propio de Friedrich Nietzsche convoca. Y no se trata de que el normalista mantenga la práctica de prescindir de los nombres propios. Por el contrario, en una famosa conferencia ha reconocido este hábito e incluso ha destacado que la función del nombre indica al fundador de una discursividad..$^{114}$ Marx y Freud, señala, Foucault son nombres propios que indican la fundación de nuevas reglas discursivas. A pesar de que Nietzsche, obviamente, debería también entrar en esta categoría, Foucault evita relacionar al filósofo alemán como referente de las prácticas racialistas y racistas del siglo XIX. Mientras que el autor de Las palabras y las cosas opta por el silencio (dimensión de ocultamiento de no deja de ser un acto político por excelencia), en cambio Peter Sloterdijk ha bosquejado los lineamientos eugenésicos de un posible antihumanismo. ${ }^{115}$ Si bien podemos interpretar su intervención como una

112 Herbert Schnädelbach [1982], Filosofía en Alemania 1831-1933, Madrid Cátedra 1991, p.128.

113 Cfr. Karl Löwith, Heidegger, pensador de un tiempo indigente, Buenos Aires, FCE, 2006 y Pierre Bourdieu [1988], La ontología política de Martin Heidegger, Barcelona, Paidós, 1991

114 Michel Foucault [1969], "Qu' est-ce qu' un auteur?", en Dit et écrits, t. I, 1954-1969, pp. 789-821.

115

Peter Sloterdijk, "Reglas para el parque humano. En respuesta a la Carta sobre el Humanismo", en Pensamiento de los Confines, n 8, 2000, pp. 9-22. provocación para épater a los humanistas, el gesto no deja de ser estrictamente nietzscheano. Y, de nuevo, el factor biologicista cobra inesperada actualidad.

\section{Referencias bibliográficas}

\section{Fuentes primarias}

\section{Obras de Friedrich Nietzsche}

Sämtliche Werke. Kritische Studienausgabe, Giorgio Colli y Mazzino Montinari (eds.), Berlín/Nueva York, Walter de Gruyter, 1980.

Obras Completas, Diego Sánchez Meca (ed.), 4 vols., Madrid, Tecnos, 2011-2016.

Fragmentos Póstumos, Diego Sánchez Meca (ed.), 4 vols., Madrid, Tecnos, 2006-2010

Otras versiones en español. Traducción de Andrés Sáchez Pascual:

El Anticristo, Madrid, Alianza, 1985.

Así habló Zarathustra, Madrid, Alianza, 1981.

Consideraciones Intempestivas I, Buenos Aires, Alianza Argentina, 1994.

Crepúsculo de los ídolos, Madrid, Alianza, 1982.

Ecce Homo, Madrid, Buenos Aires, Alianza Argentina, 1996.

La genealogía de la moral, Madrid, Buenos Aires, Alianza Argentina, 1995.

Más allá del bien y del mal, Madrid, Alianza, 1979.

El nacimiento de la tragedia, Madrid, Alianza, 1980.

Versiones del Mercurio de Francia consultadas en la Biblioteca de la Facultad de Filosofía y Letras de la UBA:

Ansi parlait Zarathoustra, Paris, Societé du Mercure de France, 1907.

Aurore, Paris, Societé du Mercure de France, 1907.

Crépuscule des idoles, Paris, Societé du Mercure de France, 
1906.

Ecce Homo, Paris, Societé du Mercure de France, 1909.

La généalogie de la morale, Paris, Societé du Mercure de France, 1900.

Humain, trop humain $\left.1^{\circ} \mathbf{p}\right)$, Paris, Societé du Mercure de France, 1899.

Par-delá le bien et le mal, Paris, Societé du Mercure de France, 1907.

La volonté de puissance, Paris, Societé du Mercure de France, 1903.

\section{Hemerografía}

El mercurio de América, Buenos Aires, 1898-1900. Dir. Eugenio Díaz Romero.

La Montaña, Buenos Aires, 1898. Dirs. Leopoldo Lugones y José Ingenieros (Ed. facs. Bernal, Unqui).

La protesta humana (desde 1903 La protesta), Buenos Aires, 1897-. Dirs. Gregorio Inglán Lafarga et al. Años consultados: 1897-1910.

La revista moderna, México DF, 1898-1903. Dir. Bernardo Couto Castillo.

Nosotros, Buenos Aires, 1907-1943. Dirs. Alfredo Bianchi y Roberto Giusti. Años consultados: 1907-1910.

\section{Libros y artículos}

Brandes, George, "Aristokratischer Radikalismus. Eine Abhandlung über Friedrich Nietzsche", en Deutsche Rundschau, n 63, 1890 (versión rioplatense: Jorge Brandes, Nietzsche, Buenos Aires, Tor, 1927).

Bunge, Carlos Octavio, Estudios filosóficos, Buenos Aires, Vaccaro, 1919

Caamaña, Raquel, Pedagogía social, Buenos Aires, La cultura argentina, 1916.

Gálvez, Manuel Amigos y maestros de mi juventud, Buenos Aires, Hachette, 1961.

González Prada, Manuel, Antología de textos, México, Ediciones de la Secretaría de Educación Pública, 1943.
Ingenieros, José, Crónicas de Viaje, Buenos Aires, Ediciones Rosso, 1920

Kropotkin, Piotr [1902], La ayuda mutua, Caracas, Monte Ávila editores, 2009.

Lesueur, Daniel, Nietzschéene, Paris, Plon, 1908 (versión local: La partidaria de Nietzsche, Buenos Aires, Biblioteca La Nación, 1909).

Mann, Thomas [1918], Consideraciones de un apolítico, Barcelona, Grijalbo, 1978.

Molina y Vedia, Julio [1904], Hacia la vida intensa, Buenos Aires, Colihue, 2006.

Renan, Ernest, Dialogues et fragments philosophiques, Paris, Calmann Lévy, 1876.

Reyles, Carlos, La muerte del cisne, París, Ollendor, 1910.

Rodó, José Enrique, Obras Completas, Buenos Aires, Claridad, 1956.

Simmel, George [1907], Schopenhauer y Nietzsche, Buenos Aires, Kier, 1944.

Vaz Ferreira, Carlos [1904], Tres filósofos de la vida. Nietzsche, James, Unamuno, Buenos Aires, Losada, 1965.

\section{Fuentes secundarias}

Arendt, Hannah [1948], Los orígenes del totalitarismo, 2 vol., Barcelona, Planeta, 1994.

Aricó, José, La cola del diablo. Itinerario de Gramsci en América Latina, Buenos Aires, Punto Sur, 1988.

Aschheim, Steven, The Nietzsche Legacy en Germany 18901990, Berkeley, University of California Press, 1992.

Asprea, Ana, "La presencia de Nietzsche en Caras y Caretas. El superhombre del tónico Sargol", en Instantes y azares, $n^{\circ} 1$, Buenos Aires, Eudeba, 2001, pp. 217-229.

Assoun, Paul-Laurent [1980], Freud y Nietzsche, México, FCE, 1984.

Austin, John [1962], Cómo hacer cosas con palabras, Buenos Aires, Paidós, 1982

Badiou, Alain [2005], El siglo, Buenos Aires, Manantial, 2008. 
Bianquis, Gèneviève, Nietzsche en France, Paris, Alcan, 1929.

Botana, Natalio [1977], El orden conservador, Buenos Aires, Hyspamérica, 1986

Bourdieu, Pierre [1988], La ontología política de Martin Heidegger, Barcelona, Paidós, 1991.

Canavese, Mariana, Los usos de Foucault en la Argentina. Recepción y circulación dese los años cincuenta hasta nuestros días, Buenos Aires, Siglo XXI, 2015.

Cominos, Marina, "The Question of Nietzsche's Anti-Politics and Human Transfiguration", en Herman W. Siemens y Vasti Roodt (eds.), Nietzsche, Power and Politics Rethinking Nietzsche's Legacy for Political Thought, Berlin/New York, Walter de Gruyter 2008.

Cragnolini, Mónica, "Nietzsche en la Argentina entre 1880 y 1945 : alusiones y citaciones en los márgenes", en Instantes y azares, $\mathrm{n}^{\circ}$ 1, 2001, pp. 107-123.

Cremonte, Martín, La recepción temprana de Nietzsche en el Río de la Plata (1890-1920), Tesis de Licenciatura, Universidad de Buenos Aires, Facultad de Filosofía y Letras, 2005.

Cúneo, Dardo, El romanticismo político, Buenos Aires, Transición, 1955.

De Lucía, Daniel, "El movimiento librepensador y la cuestión femenina (1895-1920)", en Desmemoria, n 16, 1997.

De Lucía, Daniel, "El partido socialista y la enseñanza de la moral (1890-1936)", en Boletín del FEPAI, n² 20, 2do semestre de 1992.

De Lucía, Daniel, "Los socialistas y la infancia", en Todo es historia, $n^{\circ} 355$, febrero de 1997.

Delgado, Leandro, Anarquismo en el novecientos rioplatense. Cultura, literatura y escritura, Montevideo, Estuario, 2017.

Díez, Xavier, El anarquismo individualista, Barcelona, Virus editorial, 2007.

Domínguez Rubio, Lucas (comp.), El anarquismo argentino. Bibliografía, hemerografía y fondos de archivo, Buenos Aires, $\mathrm{Ce}$ DInCl-Anarres, 2018.

Dotti, Jorge, Carl Schmitt en Argentina, Buenos Aires, Homo Sapiens, 2000.

Dotti, Jorge, La letra gótica. La recepción de Kant en la Argenti- na desde el romanticismo hasta el treinta, Buenos Aires, Facultad de Filosofía y Letras, 1992.

Eco, Umberto [1990], Los límites de la interpretación, Barcelona, Lumen, 2000.

Eco, Umberto [1992], Interpretación y sobreinterpretación, Madrid, Cambridge University Press, 1997.

Foucault, Michel [1969], "Qu' est-ce qu' un auteur?", en Dit et écrits, vol. 1, 1954-1969, pp. 789-821.

Gauchet, Marcel [1992], El inconsciente cerebral, Buenos Aires, Nueva Visión, 1994.

Genette, Gérard [1962], Palimpsestos. La literatura en segundo grado, Madrid, Taurus, 1989

Gilles Deleuze [1967], Nietzsche y la filosofía, Barcelona, Anagrama, 1994.

Godio, Julio, Historia del movimiento obrero. Inmigrantes asalariados y lucha de clases 1880-1910, Buenos Aires, Tiempo contemporáneo, 1973.

Gramsci, Antonio, Literatura y vida nacional, México, Juan Pablos Editor, 1986.

Greimas, Algirdas [1966], Semántica estructural, Madrid, Gredos, 1971 y [1976] La semiótica del texto: ejercicios prácticos, Buenos Aires, Paidós, 1983

Haar, Michael [1974], "Friedrich Niezsche", en Historia de la filosofía, vol.8, "La filosofía en el siglo XIX, México", México, Siglo XXI, 1983, pp. 398-450

Habermas, Jürgen [1985], El discurso filosófico de la modernidad, Buenos Aires, Katz, 2008.

Heidegger, Martín [1961], Nietzsche, 2 vols., Barcelona, Destino, 2000.

Hespanha, António M., "Categorías. Una reflexao sobre a prática de clasificar", en Análise Social, vol XXXVIII, 2003, pp. 823-840. Hillebrandt, Bruno, Nietzsche und die deutsche Literatur, 2 vols., Múnich, Dtv, 1978.

Jay, Martin [1988], “¿Debería la historia intelectual tomar un giro lingüístico? Reflexiones sobre el debate Habermas-Gadamer?", en Socialismo fin-de-siècle, Buenos Aires, Nueva Visión, 1990, pp. 27- 49 
Kaufmann, Walter, Nietzsche. Philosopher, Psychologist, Antichrist, Princeton, Princeton University Press, 1950.

Koselleck, Reinhart, "Introducción al Diccionario de conceptos políticos sociales básicos en lengua alemana", en Revista Ánthropos, $n^{\circ} 223,2009$, pp. 93-94.

Koselleck, Reinhart, Futuro pasado, Barcelona, Paidós, 1993.

Krummel, Frank, Nietzsche und der deutsche Geist, 2 vols., Berlín/Nueva York, Walter de Gruyter, 1974/1983.

Lavernia Biescas, Kilian, La recepción del pensamiento Nietzsche en la historia de sus ediciones, Tesis Doctoral, Madrid, UNED, 2017

Le Rider, Jacques, Nietzsche en France. De la fin du XIX siécle au temps présent, Paris, Presses Universitaires de France, 1999.

Leys Stepan, Nancy, The hours of eugenics: race, gender and nation in Latin America, Ithaca,Cornell University Press, 1991.

López, María Pía, Hacia la vida intensa. Una historia de la sensibilidad vitalista, Buenos Aires, Eudeba, 2010.

Losurdo, Domenico, Nietzsche, Il ribelle aristocratico, Torino, Bollati Boringhieri, 2002.

Löwith, Karl, Heidegger, pensador de un tiempo indigente, Buenos Aires, FCE, 2006.

Lukács, Georg [1954], El asalto a la razón, México, FCE, 1959.

Lukács, George [1954], El asalto a la razón, México, FCE, 1959.

Mailhe, Alejandra, "'El laberinto de la soledad' del genio, o las paradojas de El Hombre mediocre", en Varia Historia, vol. 29, ${ }^{\circ}$ 49, enero/abril 2013.

Miranda, Marisa A., "Matrimonio y procreación en la ortodoxia eugénica argentina", en Cuadernos del CISH, №17-18, 2005, pp. 151-178.

Nari, Marcela, Políticas de maternidad y maternalismo político, Buenos Aires, Biblos, 2004.

Niemeyer, Christian (ed.), Diccionario Nietzsche. Conceptos, obras, influencias y lenguajes, Madrid, Biblioteca Nueva, 2012.

Nolte, Ernst [1990], Nietzsche y el nietzscheanismo, Madrid, Alianza, 1995.
Páez Canosa, Rodrigo, "El culto a la risa: el joven Ingenieros y Nietzsche", en Instantes y azares, n¹, 2001, pp. 151-167.

Piossek Prebisch, Lucía, "Para una historia de las ideas. La recepción de Nietzsche", en Cuadernos de Filosofía, n 41, Abril, 1995, pp. 119-132.

Plotkin, Mariano, Freud en las pampas, Buenos Aires, Sudamericana, 2003.

Prieto, Adolfo, El discurso criollista en la formación de la Argentina moderna, Buenos Aires, Sudamericana, 2006.

Ricaurte, Soler, El positivismo argentino, Buenos Aires, Paidós, 1968.

Rivas Bravo, Noel, "Un 'raro' excluido de Los raros", en Alfonso García Morales (ed.), Rubén Darío. Estudios en el centenario de Los raros y Prosas profanas, Sevilla, Universidad de Sevilla, 1998, pp. 69-84.

Rukser, Udo, Nietzsche in der Hispanian, Bërn/ München, Francke Verlag, 1962.

Sánchez Delgado, Marcelo Javier, Chile y Argentina en el escenario eugénico de la primera mitad del Siglo $\mathbf{X X}$, Tesis de Doctorado, Santiago de Chile, Universidad de Chile, 2015.

Sarlo, Beatriz y Altamirano, Carlos [1983], "La Argentina del Centenario: campo intelectual, vida literaria y temas ideológicos", en Ensayos argentinos, Buenos Aires, Ariel, 1997, pp.161-199.

Sarlo, Beatriz, El imperio de los sentimientos, Buenos Aires, Catálogos Editora, 1985.

Sazbón, José, Nietzsche en Francia, Bernal, Universidad Nacional de Quilmes, 2009.

Schmigalle, Günther, "Darío, lector de Nietzsche", en Anales de Literatura Hispanoamericana, 47, 2018, pp. 125-140.

Schmigalle, Günther, "Darío, lector de Nietzsche", en Anales de Literatura Hispanoamericana, 47, 2018, pp. 132-133.

Schnädelbach, Herbert [1982], Filosofía en Alemania 1831-1933, Madrid, Cátedra 1991, p.128.

Schorske, Carl [1961], La Viena de fin de siglo, Buenos Aires, 2011.

Searle, John [1969], Actos de habla. Ensayo de filosofía del lenguaje, Buenos Aires, Planeta-Agostini, 1994. 
Skinner, Quentin, Lenguaje, política e historia, Bernal, Universidad Nacional de Quilmes, 2007.

Sloterdijk, Peter, "Reglas para el parque humano. En respuesta a la Carta sobre el Humanismo", en Pensamiento de los Confines, $n^{\circ} 8,2000$, pp. 9-22.

Sobejano, Gonzalo, Nietzsche en España, Madrid, Gredos, 1967.

Sternhell, Zeev, et ali. [1989], El nacimiento de la ideología fascista, Madrid, Siglo XXI, 1994.

Suriano, Juan, "En defensa de los oprimidos. Los anarquistas y la formación de una cultura de izquierda en Argentina", en Prismas: revista de historia intelectual, $n^{\circ} 6,2002$, pp. 167-177.

Suriano, Juan, Anarquistas. Cultura y política libertaria en Buenos Aires, Manantial, 2001.

Tarcus, Horacio, Marx en la Argentina: sus primeros lectores obreros, intelectuales y científicos, Buenos Aires, Siglo XXI, 2013.

Terán, Oscar, "José Ingenieros o la voluntad de saber", en En busca de la ideología argentina, Buenos Aires, Catálogos, 1986, pp. 51-95.

Thomas, Hinton, Nietzsche in German Politics and Society 1901910, Manchester, Manchester University Press, 1983.

Todorov, Tzvetan [1989], Nosotros y los otros, México, Siglo XXI, 1991.

Tomáis, Tina [1978], Breviario del pensamiento educativo libertario, Cali, Carvajal, 1988.

Vattimo, Gianni [1980], Las aventuras de la diferencia, Barcelona, Península 1986.

Verón, Eliseo La semiosis social. Fragmentos de una teoría de la discursividad, Barcelona, Gedisa, 1993.

Vezzetti, Hugo, Freud en Buenos Aires 1910-39, Buenos Aires, Punto Sur, 1989.

Wittgenstein, Ludwig [1953], Investigaciones filosóficas, BarceLona, Crítica, 2004

Zimmermann, Eduardo, Los liberales reformistas, Buenos Aires, Sudamericana, 1995.

Zum Felde, Alberto, Índice crítico de la literatura hispanoame- ricana, México, Guarania, 1954.

\section{Resumen}

El microsistema de recepción temprana de la filosofía de Nietzsche en el Río de la Plata se configuró a través de algunos operadores discursivos: el anarquismo, el idealismo arielista, el dandismo, el materialismo, la psicopatología, el anticlericalismo, el darwinismo social y el nacionalismo. En la disputa actual por la significación política de las ideas nietzscheanas, tanto la llamada "hermenéutica de la inocencia" como la interpretación "apolítica" de la filología no historizan la fuerza ilocucionaria de los conceptos. En cambio, la perspectiva de la historia conceptual, entendida como pragmática de los conceptos, ofrece la alternativa de comprender el efecto político del nietzscheanismo. Siguiendo esta última línea de análisis, este trabajo estudia la relación entre la corriente del anarconietzscheanismo y las prácticas de la eugenesia durante la hegemonía del positivismo.

Palabras clave: Friedrich Nietzsche, Estudios de recepción, Anarquismo en Argentina, Campo cultural argentino (1880-1910)

\section{Abstract: \\ Nietzsche in Buenos Aires and Montevideo anar- chism (1890-1910): Theoretical and methodological considerations}

The early reception of Nietzsche's philosophy in the Rio de la Plata was configured through some discursive operators: anarchism, arielist idealism, dandism, materialism, psychopathology, anticlericalism, social Darwinism and nationalism. On the one hand, in the current dispute over the political significance of Nietzschean ideas, both the so-called "hermeneutics of innocence" and the "apolitical" interpretation of philology do not historicize the illoquionary force of concepts. On the other hand, the perspective of conceptual history, understood as the pragmatics of concepts, offers the alternative of understanding the political effect of nietzscheanism. Following this last line of analysis, this work studies the relationship between the current of anarcho-nietzscheanism and the practices of eugenics during the hegemony of positivism.

Keywords: Friedrich Nietzsche, Reception studies, Anarchism in Argentina, Argentine cultural field (1880-1910).

Recibido el 15/06/2019 Aceptado el 30/08/2019 